\title{
Property as the Law of Democracy
}

\section{Citation}

Joseph W. Singer, Property as the Law of Democracy, 63 Duke L. J. 1287 (2014).

\section{Permanent link}

http://nrs.harvard.edu/urn-3:HUL.InstRepos:12775263

\section{Terms of Use}

This article was downloaded from Harvard University's DASH repository, and is made available under the terms and conditions applicable to Open Access Policy Articles, as set forth at http:// nrs.harvard.edu/urn-3:HUL.InstRepos:dash.current.terms-of-use\#OAP

\section{Share Your Story}

The Harvard community has made this article openly available.

Please share how this access benefits you. Submit a story.

Accessibility 


\title{
PROPERTY AS THE LAW OF DEMOCRACY
}

\author{
JOSEPH WILLIAM SINGER $†$
}

\begin{abstract}
In both his article Property as the Law of Things and his prior work, Professor Henry Smith has revitalized property law theory by emphasizing the architectural role that property plays in private law and the ways in which modular property rights reduce information costs and promote both property use and transfer. I applaud Smith's insistence that we focus on the systemic nature of property rights and the benefits of bundled entitlements. At the same time, it is important to understand the limitations of Smith's analysis.

Property law goes beyond managing the complexity of human interaction. Property not only presents a coordination problem but also a constitutional problem. Many issues fundamental to property law systems require attention to the norms, values, and ways of life that a society embraces. The problem is not just how to grease the wheels of social interaction; the problem is how to determine the character of that interaction. Value choices must be made to determine what property rights can be created, how many owners we should have, who can become an owner, how long rights last, and what obligations owners should have. Because we live in a free and democratic society that treats each person with equal concern and respect, we must interpret the fundamental values of liberty, equality, and democracy to define the set of property rights that we can recognize.
\end{abstract}

Property law is not simply about best management practices or coordination in the face of scarcity. Democracies elect leaders who pass laws that establish minimum standards for social and economic relationships compatible with our justified expectations and our considered judgments about what it means to treat others with dignity and respect. Property law is not just a mechanism of coordination; it is a quasi-constitutional framework for social life. Property is not merely the law of things. Property is the law of democracy.

Copyright (C) 2014 Joseph William Singer.

$\dagger$ Bussey Professor of Law, Harvard Law School. Thanks and affection go to Martha Minow, Mira Singer, Greg Alexander, Bethany Berger, Nestor Davidson, and Eduardo Peñalver. 


\section{TABLE OF CONTENTS}

Introduction 1288

I. Property Law as Bundled Rights in Things 1291

II. Property, Democracy, and the Social Order 1303

A. What Kinds of Property Rights Can a Democracy Recognize?

B. How Many Owners are Consistent with Democracy?....1308

C. Who Can Own Property in a Democracy?

D. How Long Do Property Rights Last in a Democracy?...1316

E. What Obligations Do Owners Have in a Democracy?...1319

III. Property, Politics, and Morality 1325

Conclusion. 1334

No Title of Nobility shall be granted by the United States.

- U.S. Constitution, Article I, Section 9, Clause $8^{1}$

We hold these truths to be self-evident, that all men are created equal, that they are endowed by their Creator with certain unalienable Rights, that among these are Life, Liberty, and the Pursuit of Happiness.

- The Declaration of Independence ${ }^{2}$

\section{INTRODUCTION}

What is property? For most people, property means the things we own. Lawyers, however, understand property as legal relations among persons with respect to things. ${ }^{3}$ Some scholars deem property to be a natural right while others view it as a delegation of sovereign power or as a package of legal entitlements. ${ }^{4}$ Property evokes

1. U.S. CONST. art. I, § 9, cl. 8.

2. THE DEClARATION OF INDEPENDENCE para. 2 (U.S. 1776).

3. RESTATEMENT (FIRST) OF PROPERTY ch. 1, introductory note (1936) ("The word 'property' is used in this Restatement to denote legal relations between persons with respect to a thing.").

4. Compare Jeremy Bentham, The Theory of Legislation 69 (Richard Hildreth trans., Oceana Publ'ns, Inc. 1975) (1802) ("Property and law are born together, and die together. Before laws were made there was no property; take away laws, and property ceases."), with Eric R. Claeys, Takings, Regulations, and Natural Property Rights, 88 CORNELL L. REV. 1549,1568 (2003) (stating that property is a natural right), and Morris R. Cohen, Property and Sovereignty, 13 CORNELL L.Q. 8, 9, 13 (1927) (stating that property is a delegation of sovereign power). 
romantic images, such as "a room of one's own" or "the American Dream" or even (paradoxically) "theft." Under any rubric or conception, property suggests a stable basis of expectation with respect to control of valued things. Stability is so important to our image of property that four current Supreme Court Justices have opined that no "established right of private property" can be altered in any way without compensation. ${ }^{5}$ At the same time, though it is undoubtedly true that justified expectations are crucial to property law, it is also true that the actions and property rights of others can affect our property and even impair or destroy its value. Others can build their own homes and block our view. They can erect McMansions that alter the nature of the neighborhood. They can default on subprime loans, leaving abandoned homes that may depress the market value of our own homes. They can compete with us and put us out of business. They can adopt condominium rules that limit what we can do in our own apartments. They can lobby for changes in zoning laws that downzone the area and prevent us from doing what we hoped to do with our own land. Property law may protect our justified expectations, but it does not freeze them in place, and it is not an easy or automatic process to determine when our expectations are justified and when they are not justified.

In truth, we face hard choices in defining property rights. Where one may see an established property right, another may, in good faith, see a case that needs to be distinguished, narrowing the scope of the property right in question. ${ }^{6}$ To figure out who is right when we confront such issues, we need to know how to think about property and property law. We need the right metaphors, frames of reference, modes of analysis, and burdens of proof; we need these things because they focus our attention in particular ways, clarifying some issues and obscuring others. Let us say we want to think deeply about property. Where should we focus our attention? What is most important to notice about American property law?

5. Stop the Beach Renourishment, Inc. v. Fla. Dep't of Envtl. Prot., 130 S. Ct. 2592, 2602 (2010) (plurality opinion).

6. See Joseph William Singer, The Rule of Reason in Property Law, 46 U.C. DAVIS L. REV. 1369, 1383-84 (2013). In Friendswood Development Co. v. Smith-Southwest Industries, Inc., 576 S.W.2d 21 (Tex. 1978), for example, the majority found the case governed by the absolute ownership rule with such confidence that it refused to apply the new law it adopted retroactively. Id. at 25-27. Conversely, the dissenting judge distinguished the cases applying the absolute ownership rule, found the rule wholly inapplicable, and deemed the current case to be one of first impression. Id. at 33 (Pope, J., dissenting). 
Professor Henry Smith has revitalized traditional property law scholarship by giving a spirited defense of some aspects of the traditional legal doctrines governing estates in land. ${ }^{7}$ This hypertechnical, abstruse set of rules appears removed from modern policy concerns or values and increasingly lacks any understandable justification. Nor has it been substantially modernized as were the subjects of torts and contracts following the legal-realist revolution in legal thought. Though Professor Wesley Hohfeld successfully recharacterized property as comprising a bundle of rights rather than a unified whole, Hohfeld's scholarship did not result in significant rationalization of the estates system. ${ }^{8}$ The estates system persisted through the twentieth century despite other vast changes in the law and became increasingly difficult to justify.

Why not abolish the estates system and allow owners to disaggregate property rights as they see fit? The existing rules require us to figure out what estate the grantor created, not what package of property rights she intended to create. If the package of rights defined by the grantor does not fit into an established estate, we choose whichever estate is closest to what the grantor intended and we ignore whatever is incompatible with that estate. When we do this, some of what the grantor intended may be discarded and ruled out of bounds and unenforceable. Why limit freedom of contract or free disposition in this way? Smith has provided a possible answer to this question. He argues that information cost economization gives us reason to define packages of rights that go along with various forms of ownership-rights in rem over things protected against everyone else in the world. ' Arguing mostly in a mode that uses cost-benefit analysis, Smith focuses on the structural role that estates play in the property system. ${ }^{10} \mathrm{He}$ goes further and argues that property's architecture plays a crucial role in private law more generally. ${ }^{11}$

7. Henry E. Smith, Property as the Law of Things, 125 HARV. L. REV. 1691 (2012).

8. See generally Wesley Newcomb Hohfeld, Some Fundamental Legal Conceptions As Applied in Judicial Reasoning, 23 YALE L.J. 16 (1913). For explanation of the significance of Hohfeld's scholarship, see Joseph William Singer, The Legal Rights Debate in Analytical Jurisprudence from Bentham to Hohfeld, 1982 WIS. L. REV. 975, 1056-59. Hohfeld's scholarship did help to combat Lochnerism by affirming the legitimacy of legislative regulation of property rights, on the grounds that limitation of a few rights in the bundle did not necessarily result in a deprivation of property without due process of law. See Hohfeld, supra, at 35 (noting that privileges and rights can exist even when the other is lacking).

9. Smith, supra note 7, at 1693-94.

10. Id. at 1694 .

11. Id. 
Part I explains the major contributions of Smith's view. I then argue that Smith's focus on property law as a solution to a coordination problem fails to address the ways in which property law is also a constitutional problem. It may be true that we need to grease the wheels of social interaction, but it is also true that we need to judge and regulate the character of that interaction. Smith's argument depends on assumptions that he does not make explicit. We must explicate these because property law implicates fundamental value choices that must be addressed first before analyzing human interaction and coordination within a chosen social and political order.

Part II gives specific examples of the ways in which property law shapes social life and both reflects and promotes fundamental values. We see underlying value choices in determining what property rights can be created, how many owners we should have, who can become an owner, how long rights last, and what obligations owners should have.

Part III widens the lens to explain the reasons we need to consider the teachings of moral, political, and legal theory in addition to economics to sensibly analyze and interpret the basic values of a free and democratic society that treats each person with equal concern and respect. Liberty, equality, and democracy are not selfdefining. They are essentially contested concepts and there is much disagreement about what they mean. At the same time, there are also large areas of overlapping consensus about what these values require.

Smith is right that the nature of the things we control through property law should lead us to adopt certain appropriate strategies for managing and coordinating our access to and our control of them. Coordination, however, is only a problem because we live in a liberal democracy comprised of free and equal persons. Understanding coordination therefore requires an understanding of both freedom and equality. Property is more than the law of things; property is the law of democracy. Property law shapes social relations, and because we live in a free and democratic society that aspires to treat each person with equal concern and respect, a crucial function of property law is to interpret what that means.

\section{PROPERTy LAW As BundLED RightS IN THINGS}

Professor Henry Smith has performed an invaluable service to property law theory by conceptualizing property not simply as an 
individual right or bundle of rights but as a framework for "interactions of persons in society" as well as the foundation and infrastructure of private law. ${ }^{12}$ Smith asks us to think about property as the "law of things." 13 This evocative metaphor not only harkens back to William Blackstone's grand distinction between the "rights of persons" and the "rights of things" ${ }^{14}$ but also subtly dissents from the legal realist conception of property as a bundle of rights with respect to things. ${ }^{15}$ Smith agrees with the legal realists that property ownership does comprise a bundle of rights, that those rights are not absolute, and that some of them can be individually alienated. ${ }^{16} \mathrm{He}$ emphasizes, however, that the package of rights is not infinitely malleable. Rather, some bundles of rights must stick together for the property system to work properly. ${ }^{17}$ Rather than bundles of rights that can be disaggregated at will, Smith argues for what I will call bundled rights. Some packages of rights are crucial to the functioning of the property system and the rest of private law as well. For this reason, the law structures property rights into modules and places limits on the power of owners to disaggregate the rights that are packaged in these modules. ${ }^{18}$ Some bundles of rights support the property system itself and cannot be dismantled without undermining the foundations of the house. There is, Smith argues, a systemic logic to property and

\section{Id. at 1691 .}

13. Id.

14. 1 William Blackstone, COMmentaries *121 (titling Book the First "Of the Rights of Persons"); 2 id. *1 (titling Book the Second "Of the Rights of Things").

15. Cf. Restatement (FIRST) OF PROPERTY ch. 1, introductory note (1936) ("The word 'property' is used in this Restatement to denote legal relations between persons with respect to a thing."); $i d$. ("Legal relations between persons can be of widely differing types. Clarity of thought and exactness of expression require the analysis and subdivision of legal relations into types having different signifances. This analysis is made in $\$ \S 1-4$ defining respectively those legal relations designated by the words 'right,' 'privilege, ' 'power' and 'immunity.'”); Hohfeld, supra note 8 , at 30-32 (explaining the analytical differences among rights, privileges, powers, and immunities).

16. See Smith, supra note 7, at 1696, 1699, 1710 (incorporating these concepts into his argument).

17. See id. at 1693 ("Property organizes this world into lumpy packages of legal relationslegal things-by setting boundaries around useful attributes that tend to be strong complements."); see also Joseph William Singer, Essay, Democratic Estates: Property Law in a Free and Democratic Society, 94 CORNELL L. REV. 1009, 1021 \& n.44, 1022 (2009) (making this point and arguing that Smith's scholarship helps to emphasize and justify it).

18. See Smith, supra note 7, at 1693-94 (arguing that the property system depends on its modular structure). 
property law that not only explains much of existing law but also gives us a normative framework for judging it. ${ }^{19}$

These insights have played an extremely helpful role in current property theory. In recent years, the estates system has been going out of fashion and taking up less time in many property law courses. ${ }^{20}$ Property professors pay more attention these days than in the past to trespass, covenants, easements, leases, zoning, and real-estate transactions, not to mention intellectual property and regulatory takings. In law practice, future interests are not the focus of housing or of commercial real-estate transactions, though they remain important for trusts and estates law. To the current generation, the law of estates in land seems technical, bizarre, and antiquated. This is partly because of its arcane terminology and partly because many traditional rules have archaic justifications.

More importantly, the idea that there are only a few bundles of rights one can create also contradicts the modern preference for freedom of contract, evident in the myriad covenants, conditions, and restrictions we see in property owners' associations. Libertarians can hardly be overjoyed about legal rules that force property transactions into a few, preset bundles, rather than allow owners to disaggregate property as they like. ${ }^{21}$ Progressives cannot be too attracted to rules

19. See id. at 1691-94.

20. Cf. D. Benjamin Barros, Toward a Model Law of Estates and Future Interests, 66 WASH. \& LEE L. REV. 3, 17-20 (2009) (proposing a way to fix the unnecessary complexity of the estates system); T.P. Gallanis, The Future of Future Interests, 60 WASH. \& LEE. L. REV. 513, 514-15 (2003) (arguing for reform of the estates system to reduce its complexity); Louise A. Halper, $Q$. Why is this Course Different from All Other Courses? A. Maybe It's Not, 22 SEATTLE U. L. Rev. 965, 970 (1999) (reviewing John P. Dwyer \& Peter S. Menell, Property LAW and Policy: A Comparative Institutional Perspective (1998)) (noting the smaller number of estates-related cases in a leading casebook).

21. I use the terms "libertarian," "conservative," "liberal," and "progressive" in their modern senses as used in contemporary political rhetoric. Broadly speaking, libertarians are attracted to what they view as a "limited state" that protects individuals from harm, enforces contracts, and protects property rights. They favor freedom of contract because they see it as a core aspect of liberty; for that reason, they are likely to view with great suspicion any regulatory rules that limit the packages of property rights that can be created because those packages interfere with freedom of contract. Conservatives often adopt a libertarian stance toward economic regulation (thus agreeing with libertarian views on freedom of contract), but they tend to couple that commitment with support for regulations designed to promote "traditional values" in the areas of sexuality and family life. Liberals or progressives tend to favor regulation of market relations for a variety of reasons, such as fairness, distributional norms, and the promotion of minimum standards for market relationships. Just as conservatives may flip their deregulatory stance when dealing with matters of sex and family, liberals and progressives tend to adopt a libertarian approach to such matters rather than the regulatory one they adopt with respect to economic matters. 
that consolidate powers in owners while leaving nonowners without access to the things they need. And efficiency theorists tend to talk about property rights as if they were merely transaction costsimpediments to the transfer of resources to those who value them most highly. ${ }^{22}$ Against this united front, Smith shows us how things would be much worse for us if we did not have a system of bundled rights. ${ }^{23} \mathrm{He}$ has presented a coherent picture of some reasons why bundled rights matter and has convincingly demonstrated that property law is part of the infrastructure of private law and a foundation for social life.

To explain why property law plays this pivotal role, Smith argues that property presents us with a complex coordination problem. We need to "manage[] the complexity of human interactions." ${ }^{24}$ Because property concerns scarce resources and because people want to use resources for their various purposes, we need a way to allocate powers over those resources, especially use rights. When resources are scarce, creating rules about property use is beneficial; however, such rules are also costly to create, define, and enforce. Smith argues that the focus of property law is to minimize the costs of information we need to figure out who gets to do what with what thing. ${ }^{25} \mathrm{We}$ do this by granting specific things to owners, with a package of powers "in rem" giving them general rights to control a thing against the entire world. ${ }^{26}$ If we do this, we can minimize information costs by allocating gatekeeping powers over particular things. ${ }^{27}$ Those powers are protected by a general right to exclude others from particular objects of property. This "exclusion strategy" not only grants owners capacious powers to control things but also implies an architecture for the entire property system. ${ }^{28} \mathrm{We}$ divide the world into things and then allocate those things among owners, giving them the power to exclude

22. See Thomas W. Merrill \& Henry E. Smith, Essay, What Happened to Property in Law and Economics?, 111 YALE L.J. 357, 380 (2001) (explaining how efficiency theorists tend to view property as a bundle of rights that can be recombined or disaggregated at will to promote human interests and arguing that such theorists do not sufficiently understand the ways that limits on disaggregation of property rights might promote efficiency rather than simply impede it).

23. See Smith, supra note 7, at 1720-22 (discussing the implications and advantages of his approach).

24. Id. at 1725 .

25. Id. at $1691,1698,1700-13$.

26. Id. at $1702-08$.

27. Id. at $1709-13$.

28. Id. at $1709-16$. 
others from things they own as well as general powers to use them and transfer them. Then we establish public recording offices to make it possible for anyone to find out who is the owner of each thing.

All this minimizes the costs of figuring out whom to talk to if you want access to a thing you do not own, and it frees all of us from having to explain to others our own decisions about how to use our own things. Sometimes we disengage from this exclusion strategy and ask the courts to engage in nuanced, contextual determinations of the distribution and scope of particular property rights, but Smith argues that we adopt this "governance strategy" only if the benefits of doing so outweigh the costs. ${ }^{29} \mathrm{He}$ emphasizes that we can generally minimize costs by eschewing such contextual analyses. ${ }^{30}$ Governance strategies are the exception, not the rule. ${ }^{31}$ Rather than treating each case as a particular contextual problem about who gets to control the property, Smith argues that we should see the structural reasons for formal generalizations as well as preset packages of rights through assignment of ownership and general rights to exclude, all of which enable people to interact with others at manageable cost. ${ }^{32}$

We all have reason to celebrate this new turn in property theory. Smith has reminded libertarians that they not only favor freedom of contract, but they also favor the rights of owners and their freedom from undue limitations on their ability to choose how to use their own property. It is easy to see how the freedom to disaggregate property rights at will may wind up impinging on property rights and freedoms that libertarians may cherish. Consider how limited our freedom would be if we had to comply with limitations imposed by those who owned our property in the $1640 \mathrm{~s}{ }^{33}$ Consider the constraints we would face if much of the land in the United States was inalienable because it was "entailed" and destined to stay within a particular family. ${ }^{34}$ Consider the federal statute that restored the rights of condominium owners to fly the American flag from their balconies despite any

\footnotetext{
29. Id. at $1693-94,1703-05$.

30. Id.

31. Id.

32. Id. at $1693-94$.

33. See Joseph William Singer, Property § 7.1, at 300 (3d ed. 2010) (describing how "land use was far from free because it was always intimately connected with services owed to a higher lord, all the way up to the monarch").
}

34. Id. § 7.7.1, at 323-25. 
condominium association rules to the contrary. ${ }^{35}$ Libertarians who favor freedom of contract may have opposed that law, but others who value the freedom of owners to use their property as they see fit may have applauded it.

Progressives can also celebrate the notion that owners have freedoms that cannot be taken away by private contract or will. Consider the Fair Housing Act ${ }^{36}$ which guarantees access to housing without regard to race or religion, ${ }^{37}$ or the implied warranty of habitability that guarantees tenants livable housing. ${ }^{38}$ Smith has also reminded efficiency aficionados that markets cannot work without the bundled property rights that form the basis for market transactions and that minimize the costs of determining who gets to control the things in the world. Property rights are not merely impediments to resources ending up in the hands of those who value them the most; they are one of the basic tools that allow markets to exist in the first place. They are inherently valuable because they enable people to act, to invest, to plan, and to exchange goods and services. They establish bargaining power that protects individuals from being forced to comply with the will of others; they are a significant part of what makes free markets "free."

Smith teaches property law scholars several crucial lessons. ${ }^{39}$ First, he emphasizes that property is a system and not just an individual entitlement. The recognition and exercise of property rights inevitably affect others. Property rights and externalities are born together; you cannot have one without the other. ${ }^{40}$ The assignment of ownership to one person necessarily affects others by giving the owner the power to exclude others from the resource even

35. Freedom To Display the American Flag Act of 2005, Pub. L. No. 109-243, § 3, 120 Stat. 572, 572-73 (2006) (codified as amended at 4 U.S.C. $\$ 5$ note (2012)).

36. Fair Housing Act, 42 U.S.C. $\S \S 3601-3619$ (2006).

37. Id. $\$ 3604$.

38. See Javins v. First Nat'l Realty Corp., 428 F.2d 1071, 1077 (D.C. Cir. 1970) ("In our judgment the common law itself must recognize the landlord's obligation to keep his premises in a habitable condition.").

39. In addition to Smith's article Property as the Law of Things, supra note 7, see generally, for example, Merrill \& Smith, supra note 22; Henry E. Smith, Exclusion and Property Rules in the Law of Nuisance, 90 VA. L. REV. 965 (2004); Henry E. Smith, Exclusion Versus Governance: Two Strategies for Delineating Property Rights, 31 J. LEGAL STUD. S453 (2002); Henry E. Smith, On the Economy of Concepts in Property, 160 U. PA. L. REV. 2097 (2012); Henry E. Smith, Property and Property Rules, 79 N.Y.U. L. REV. 1719 (2004).

40. Joseph William Singer, How Property Norms Construct the Externalities of Ownership, in PRoperty AND COMmunity 57, 59 (Gregory S. Alexander \& Eduardo M. Peñalver eds., 2010). 
if they need it. Externalities only come into play if we have property rights because, in a state of nature unencumbered by law, everyone acts to further their own interests. There is no basis for saying that something wrongly impinges on others if we do not have a sense of what we have a right to be protected from. Given that law identifies the interests that deserve legal protection, we can only determine whether an action causes an externality by reference to a normative framework that distinguishes self-regarding from other-regarding actions.

Because property rights necessarily affect others, they must be regulated to ensure that they are compatible with the property and personal rights of others. The scope of a property right depends on the effects on others with whom we are willing to live. An owner's interest in controlling a thing cannot be viewed in isolation from the interests of others. Property rights must be tailored to ensure that they are mutually compatible with each other, and the distribution and packaging of property rights must be structured so that they work over time, given the realities of human life. Creating an architecture for property law must take into account the systemic effects of various bundles of rights as they are exercised over time. That requires limiting the ability of owners to unbundle property rights when doing so undermines the smooth functioning of the system itself.

Second, Smith asks us to focus on the basic structure of the property system. In so doing, he reminds us that property rights must be defined prior to markets; they are a foundation upon which markets rest. We cannot act unless we are free to act in some place; no property rights, no markets. We cannot buy something if we do not have entitlements to exchange with others; no property rights, no contracts. And we cannot make choices about what to do without having capacious powers over discrete objects in the world; no property rights, no freedom. Property rights precede actions, contracts, and markets. In important ways, property precedes both liberty and efficiency.

Property precedes liberty because we cannot decide how to live if we are not given general powers to choose how to use the things we own. If we have to ask permission for each thing we want to do, or if we have to consult a list to make sure we are not engaging in a prohibited action, we will be inhibited from living our lives on our own terms. Property precedes efficiency because we cannot use market values to define property rights since market values are dependent on an initial distribution of property that is then 
exchanged within those markets. Determining what individuals are willing and able to pay for an entitlement requires positing a distribution of property before the efficiency analysis even begins. This does not mean that efficiency analysis cannot help us think about the appropriate distribution of property; Smith and Professor Thomas Merrill have explained why property matters to economic analysis. ${ }^{41}$ But it does mean that the kind of analysis we use to choose the basic structure of property law may be different from the kind of analysis we use to determine the scope of rights within the system.

Third, Smith reminds us that there are good reasons why the law places distinct limits on our freedom to disaggregate property rights. ${ }^{42}$ There are some bundles of rights we are not, and should not, be allowed to create. Property comes in discrete modules that enable us to know what we own and what we can do with it. Those modules not only give us valuable information; they free us from unwarranted restrictions. They enable us to deal with others on terms we can understand. They protect our justified expectations by enabling us to know what rights we get when we buy something. They free us from having to bargain about every basic thing we expect to get when we engage in a transaction. They allow us to take certain things for granted. ${ }^{43}$ For example, we have abolished the fee tail and most restraints on alienation of fee simple interests to ensure both free use of land and transferability. ${ }^{44} \mathrm{We}$ have passed consumer protection laws in every state to ensure that we get what we pay for. ${ }^{45}$ We have building-construction codes, housing codes, and zoning laws to ensure that our property is safe and protected from incompatible uses. ${ }^{46}$ The set of bundled rights we are entitled to create must be limited by law to promote both freedom and efficiency.

In sum, Smith argues that the systemic, foundational, and modular nature of property implies that it can function only within

41. Merrill \& Smith, supra note 22, at 398 .

42. See generally Smith, supra note 7 (arguing that a modular theory of property, in which certain rights are grouped together, provides a better explanation of property law than a theory of detachable sticks).

43. Joseph William Singer, Subprime: Why a Free and Democratic Society Needs Law, 47 HARV. C.R.-C.L. L. REV. 141, 157-58 (2012).

44. SINGER, supra note 33, § 7.7.1, at 323-25.

45. See generally CAROLYN L. CARTER, NAT'L CONSUMER LAW CTR., CONSUMER PRotection IN THE STATES: A 50-STATE REPORT ON UNFAIR AND DECEPTIVE ACTS AND PRACTICES STATUTES (2009), available at http://www.nclc.org/images/pdf/pr-reports/reportudap-50-states.pdf.

46. See infra notes $145-55$ and accompanying text. 
the framework of a workable architecture. Property law provides that architecture. ${ }^{47}$ I wholeheartedly support these insights, and Smith's care in formulating and explaining them marks an invaluable contribution to our understanding of both property as a social institution and of property law. At the same time, there are limitations to the way Smith analyzes the architecture of property law. He focuses on property as a coordination problem or as problem of minimizing the costs of managing the complexity of human interaction. $^{48}$ Though these issues are both important and fundamental to the property system, they take our attention away from values and value choices that are not only basic elements of property law but are also fundamental to both private and public law more generally.

Smith is quite right that property poses a coordination problem, but property also poses a constitutional problem. By constitutional I do not mean to refer only to constitutional law, but to the fact that property institutions are fundamental to social life, moral norms, political power, and the rule of law. ${ }^{49}$ Property institutions not only regulate the complexity of human interaction, but also shape the character of those interactions. Property is not only about the allocation of scarce resources, the management of complex information, or the coordination of land use among competing users; it is about our way of life. If this is true, then property law should reflect and shape our deepest values. Property is not just about information or complexity; it is about promoting "Life, Liberty and the Pursuit of Happiness." ${ }^{50}$ Information costs help us manage in the world, but they are neither the only thing we care about nor the most important. Property is about the social order; it reflects and enables our conception of what it means to live in a free and democratic society that treats each person with equal concern and respect. ${ }^{51}$

Smith argues that there is a structural logic to property law that is helpful no matter what purposes we have or what values we

47. See Smith, supra note 7, at 1700 (arguing that "[t]here is a basic architecture of property, and many features of property follow from it").

48. See id. at 1699 (arguing that the "architecture [of property] responds ... to the problem of managing the complexity of interactions between private parties with respect to a variety of attributes of resources in a world of positive delineation costs").

49. See Gregory S. Alexander, Commodity \& Propriety: Competing Visions of Property in AMERICAN LEGAL THOUGHT, 1776-1970, at 1-2 (1997).

50. THE DECLARATION OF INDEPENDENCE para. 2 (U.S. 1776).

51. AlEXANDER, supra note 49, at 1-2; Singer, supra note 43, at 167. 
cherish. He hopes to eschew reliance on any particular moral or political theory such as utilitarianism. ${ }^{52}$ His normative goal is to analyze what makes property systems work well at minimum cost, given the realities of human life.$^{53} \mathrm{He}$ wants to focus on the structures of property that are necessary to enable any legitimate values to be promoted. ${ }^{54}$ Yet despite these ambitions, Smith does not eschew value choices. Indeed, he makes a number of legitimate but unstated normative assumptions about the values that a property system should promote. He assumes (1) that every person is entitled to become an owner, (2) that opportunities to acquire property are freely available, (3) that ownership is widely dispersed, (4) that owners are presumptively free to use their property as they wish and to determine the course of their own lives, and (5) that people are entitled to quiet enjoyment of their property. These are widely shared norms that reflect widely shared values. The property system whose structure Smith analyzes embodies the values of liberty, equality, and stability, among others. But these norms are not self-defining even if the Declaration of Independence would have us view them as selfevident. These values require interpretation. Failure to address the meaning of these values directly prevents us from seeing the foundational choices needed to create a property law system compatible with these values.

Smith's focus on the costs and benefits of alternative strategies for organizing property rights inevitably utilizes economic theory more intensively than other potentially relevant frames of reference or methods of analysis. But we can neither understand our property law system nor adequately judge it unless we supplement economic analysis with the disciplines of moral theory, political philosophy, history, and legal theory. ${ }^{55}$ Property law in contemporary America is

52. See Smith, supra note 7, at 1719 (suggesting that property law promotes a variety of values, including "efficiency, fairness, justice, and virtue").

53. See id. at 1691-94.

54. Cf. id. at 1725 (mentioning a number of potential "goals" of property law, such as "autonomy, privacy, investment, planning, and appropriability according to criteria of efficiency, fairness, and morality").

55. See, e.g., Singer, supra note 43, at 144; Joseph William Singer, Property Law as the Infrastructure of Democracy, Lecture at the University of Florida Levin College of Law (2011), in 11 Powell on ReAl Property WFL11-1, WFL11-3 (Michael Allan Wolf ed., 2013) [hereinafter Singer, Infrastructure of Democracy]; Joseph William Singer, The Anti-Apartheid Principle in American Property Law, 1 ALA. C.R. \& C.L. L. REV. 91, 109 (2011) [hereinafter Singer, Anti-Apartheid Principle]; cf. Joseph William Singer, Normative Methods for Lawyers, 
not only about the allocation of scarce resources, but also about the legal framework of a free and democratic society that treats each person with equal concern and respect. Property is not just a choice between exclusion and governance strategies; it is a choice between feudalism and democracy, between slavery and freedom, between bureaucratic expertise and electoral politics, between stability and change, between a libertarian conception of freedom and a liberal one, between the norms of formal equality and the norm of equal opportunity. Property affects polity. Property may be the law of things, but property is also the law of democracy.

Smith argues that property forms the baseline for private law. ${ }^{56} \mathrm{I}$ agree. He also argues that we should consider the best structure for property law before looking into the values that property should promote. ${ }^{57}$ He suggests that we want a system that allows us to best achieve our values at the lowest cost, no matter what those values happen to be. But the norms associated with a free and democratic society imply structural constraints of their own. They are not things we can add on later; they inform the basic structure of property rights. Smith does not ignore such values; he simply assumes them. But anyone who pays attention to contemporary American politics will immediately recognize that we have fundamental value conflicts about the meaning of liberty, equality, and democracy. Depending on our conception of those concepts, we will define the basic structure of property law very differently.

Smith is right that property has an architecture that forms a foundation for social life, but property also has a constitution-a set of norms and values that defines the legitimate social relationships that can be recognized in a free and democratic society that treats each person with equal concern and respect. We could manage the complexity of human interaction by creating a dictatorship and giving all property to a supreme leader. We could abolish all regulatory laws, allowing owners to do whatever they like with their property. We could allow people to choose to become slaves if they wish. We could delegate power to an established church to divvy up property in light of religious doctrine. We could disable women from owning

56 UCLA L. REV. 899, 906 (2009) [hereinafter Singer, Normative Methods] (arguing that lawyers should apply principles from "moral and political theory").

56. See Smith, supra note 7, at 1703 ("[M]odules . . permit private law to manage highly complex interactions among private parties.").

57. See supra note 54 and accompanying text. 
property. We could segregate housing by race. We could abolish corporations. We could allow condominium associations to regulate the intimate details of life for their inhabitants, or we could free unit owners from oppressive restrictions. We could protect homeowners from being deceived by subprime mortgage sales tactics, or we could live with laissez faire. We could allow landlords to use self-help to evict tenants at will by putting their belongings on the street at a moment's notice, or we could require court evictions to end tenancies. We could give landlords the power to regulate tenants' personal lives, or we could prohibit that. All these possibilities would have effects on information costs and the complexity of human relationships. But they would also fundamentally affect our way of life.

The values of a free and democratic society are both more fundamental and more contested than the value of minimizing information costs or the value of managing complex human interactions. The question is not just how to simplify human interactions; the question is how to define the minimum standards for human interactions compatible with the values of a free and democratic society that treats each person with equal concern and respect. Information costs are important to the structure of property law, but political, moral, and rule of law norms must be satisfied first. Costs of human interaction become relevant only within a normative framework that defines what kinds of property arrangements are compatible with the ideals of freedom, equality, and democracy.

Importantly, not all costs can be quantified, and many important features of property law cannot be explained by reference to monetary costs. Both the architecture of the property system and also the technical details of some property law doctrines depend on norms of morality and justice that embody our deepest values. Rather than a quantitative problem of how to minimize costs or a structural problem of how to manage complexity, we face an interpretive problem of how to define the values that shape the legal infrastructure of a free and democratic society. That means we also confront a normative problem of how to define the contours of social relationships that treat each person with equal concern and respect and that are compatible with the values of a free and democratic society.

Smith does not ignore the values of freedom, equality, and democracy. Indeed, his cost-minimization program is designed to 
promote all those values. ${ }^{58}$ My argument is that property theorists need to pay as much attention to the contested concepts of liberty, equality, and democracy as they do to efficiency and to costs and benefits. Smith is absolutely correct that property law is about the architecture of private law and the management of complex human interactions, but it is also about the infrastructure of a free and democratic society, and that requires analysis and interpretation of fundamentally contested normative concepts. Smith's insights depend on a normative framework that is implicit in his analysis; the normative framework merits separate attention because we cannot engage in meaningful analysis of information costs (or any other costs) without first discussing the social and legal framework within which those costs are computed. Cost-minimization analysis will come out very differently if the framework is a libertarian one or a liberal one; it will similarly be different depending on whether utilitarianism, rights, fairness and justice, or virtue theory are the animating normative impulses. If we widen the lens to include the insights of political and moral theory, as well as the traditions of the common law and the norms associated with the rule of law, we will see the constitutional questions lurking behind the coordination dilemmas upon which Smith focuses his attention. We will see why property is the law of democracy.

\section{PROPERTY, DEMOCRACY, AND THE SOCIAL ORDER}

Professor Henry Smith wisely proposes that we consider the deep structure of property law. That means going back to first principles. If we take this advice seriously, then it becomes evident that property law is a constitutional problem because the norms and values of a free and democratic society limit the kinds of property rights that can be created. Not only do democracies limit the kinds of property rights that can be recognized, but they also have something to say about how many people can be owners, who can become an owner, how long their rights last, and what obligations go along with their rights.

\section{A. What Kinds of Property Rights Can a Democracy Recognize?}

Property law does more than manage the complexity of human interactions to ensure low-cost coordination among people with

58. See supra note 54 and accompanying text. 
regard to control of things. Property law establishes a baseline for social relations compatible with democracy, both as a political system and a form of social life. Property law not only simplifies and promotes human interaction, but it also entails substantive choices about the type and scope of property rights that a free and democratic society can recognize without violating its deepest values. We have, for example, abolished feudalism, slavery, primogeniture, male control of marital property, racial segregation, the fee tail, and debtors' prisons. $^{59}$ We have abolished self-help in landlord-tenant relations; we prohibit landlords from putting the tenant's belongings on the street if a rent check is a day late. We require landlords to provide habitable housing. We have abolished strict foreclosure of mortgages. We have abolished racially restrictive covenants. We have enacted zoning and environmental laws and we have protected consumers from unfair and deceptive business practices. ${ }^{60}$ The host of regulations we see both in state and federal law establishes minimum standards for social relationships compatible with our choice to live in a democracy and to promote freedom and equality. Basic democratic values limit the kinds of property rights that the law will recognize, and they define particular bundles of rights that cannot be created. The modules that define the basic components of the property system must satisfy these fundamental norms first before we can shape them to manage the complex human interactions that remain.

Consider slavery. It arguably lowers the cost of human interaction by diminishing the number of people who are entitled to make choices. With fewer people to deal with, the costs of interactions go down. Owners need not obtain information from slaves about their preferences because their preferences do not count. Slaves themselves have few choices to make; they do what they are told. We could drastically reduce the number of property owners by enslaving three-quarters of the population. Of course, this places management costs on the slaveowners, but those costs are offset by the fact that the owners do not have to negotiate with their slaves over the terms of employment; they can simply order them around. If the slaves resist, they can control them by force. Perhaps human desires are less satisfied in the aggregate in such a system because a majority of people are stifled in their ability to live their lives on their

59. Singer, Infrastructure of Democracy, supra note 55, at WFL11-3; Singer, supra note 43, at $145,148,150$.

60. For discussion of these laws and regulations, see infra Part III. 
own terms. And perhaps law enforcement costs go up if the slaves are restless and resist orders. But the complexity of human interactions has arguably been reduced (at least as a matter of defining the legal rights that people have), and coordination problems have been solved by giving dictatorial power to slaveowners and reducing the number of people who have free will.

Of course, one can argue that the cost and difficulty of managing slaves may outweigh the benefits in reduced information costs, and one could construct an argument that demonstrates that slavery is more costly than freedom in terms of coordination among persons or in reducing the information needed for social interaction. My point here is not to argue which of these interpretations is correct. My point is that talking about slavery in terms of information costs is wholly beside the point. To say that slavery is or is not an option because one choice or the other minimizes information costs is to give an irrelevant reason for the choice being made. We abolished slavery not because it economized on information or because it made human interaction too complex. We abolished it because it denies individuals the freedom and equal dignity they deserve. We do not choose between slavery and freedom on the grounds of complexity or efficiency or information costs. We choose between them on the basis of fundamental values about the inalienable right of each individual to life, liberty, and the pursuit of happiness. We minimize costs of social interaction after we have made the decision to abolish slavery and to promote equal human dignity, not before. Slavery is not a property right that a democracy can legitimately recognize.

Slavery is sometimes thought to be an extreme example that has no relevance to contemporary life. But consider what has occurred within my own lifetime. The states that still recognized male privileges in tenancies by the entirety abolished them. ${ }^{61}$ The separate property states adopted equitable distribution statutes that treat women as equal partners with men in marriage. ${ }^{62} \mathrm{We}$ abolished racial segregation and disability discrimination, protected women from sexual harassment in the workplace, and allowed gay and lesbian parents to adopt children. ${ }^{63}$

61. SINGER, supra note $33, \S 8.2 .3$, at $356-57$.

62. Id. § 9.3.1, at 394-96.

63. Id. $\$ 2.6$, at $45-77$. See generally William E. Adams, Jr., Whose Family Is It Anyway? The Continuing Struggle for Lesbians and Gay Men Seeking To Adopt Children, 30 NEW ENG. L. REV. 579 (1996) (analyzing shifting legal rules about gay and lesbian adoption of children); Christopher Massaro, Note, The Role of Workplace Culture Evidence in Hostile Workplace 
For contemporary examples, consider same-sex marriage and subprime mortgages. Same-sex marriage concerns the rights of individuals to participate in a particular property arrangement. In many states, the question is not just what to call the arrangement (marriage, civil union, or contract) but whether the same-sex couple can take on the rights and obligations associated with marriage at all. As for subprime mortgages, we are engaged in a continuing debate about whether or not they should be prohibited or regulated. We are debating whether to forgive principal payments on underwater mortgages so we can get the economy moving again. Should we "let the market take care of it," or should laws be changed to prevent subprime mortgages from ruining families and national economies in the future? Should we apply or amend consumer protection laws to prohibit granting mortgages to people who are not likely to be able to pay them back? Should we rewrite mortgage contracts to reflect current market values? Should we adopt new banking and mortgage regulations to prevent this problem from recurring? Should mortgages be dischargeable in bankruptcy? ${ }^{64}$ These issues implicate not only efficiency concerns, but also questions about what kinds of contracts are so unfair or deceptive that they are the moral equivalent of picking the consumer's pocket, as well as questions about what protections should be in place to enable people who are down on their luck to recover and go on with their lives. These are not just issues of imperfect information; they are normative questions about what conduct promotes (and infringes on) human dignity.

Smith wrongly assumes that those of us who focus on the values promoted by property law cannot see any value in a modular approach to property. He suggests that we want every case to be treated as if our goal were to enact our most fundamental values and that we see no advantage in creating baselines, presumptions, and bundled rights. ${ }^{65}$ Yet none of the modern proponents of a values-

Environment Sexual Harassment Litigation: Does Title VII Mean New Management or Just Business as Usual?, 46 N.Y.L. SCH. L. REV. 349 (2002) (exploring ways to prove a hostile environment).

64. See generally Joseph William Singer, Foreclosure and the Failures of Formality, or Subprime Mortgage Conundrums and How To Fix Them, 46 ConN. L. REV. (forthcoming 2014), available at http://papers.ssrn.com/sol3/papers.cfm?abstract_id=2390097 (discussing the complexity of the subprime mortgage market and the legal choices needed to be made to determine how to best regulate it).

65. See Smith, supra note 7, at 1717 (arguing that "[1]egal realists and their successors object to delineation strategies that are not fully congruent with [the basic] purposes" of property law). 
based approach to property law has actually argued against the idea that property law forms part of the structure of society; nor has anyone argued that we can live with a property system that has no doctrine, no rules, no modules, no presumptions, and that we can replace all that with direct consideration of values like virtue and equality in every case. ${ }^{66}$ There are moral theorists who are particularists who eschew all generalizations. ${ }^{67}$ Yet few legal realists pursued that path; Hohfeld and legal realists like Karl Llewellyn argued for the exercise of judgment in the interpretation of doctrine, but not its abolition. ${ }^{68}$ And Professor Thomas Grey argued against an inherent objective, value-free logic to property rights, but he did not argue that there were no reasons to be in favor of particular bundles of rights. ${ }^{69}$

I do not know anyone who thinks that we would be better off if we had no legal doctrine at all and just treated each property case as one of first impression. I also do not know anyone who thinks that it is not important to develop property rights that are workable, transparent, and suited to the satisfaction of legitimate human preferences, desires, and values. Nor have progressive property

66. Neither Professor Gregory Alexander nor Professor Eduardo Peñalver, for example, argues that property law doctrine should be discarded and that every case should be treated as if it were a case of first impression. See Gregory S. Alexander, The Social-Obligation Norm in American Property Law, 94 CORNELL L. REV. 745, 752 (2009) (arguing for the "social-obligation norm" theory to fill the gap in American property law); Eduardo M. Peñalver, Land Virtues, 94 CORNELL L. REV. 821, 888 (2009) (arguing for an introduction of "virtue ethics" in property law but also noting that economic considerations are still important).

67. E.g., Mark Timmons, Moral Theory: An Introduction 245-66 (2002); Robert Audi, Ethical Generality and Moral Judgment, in CONTEMPORARY DEBATES IN MORAL THEORY 285, 285-304 (James Dreier ed., 2006); Mark Norris Lance \& Margaret Olivia Little, Defending Moral Particularism, in CONTEMPORARY DEBATES IN MORAL THEORY, supra, at 305, 305-21.

68. See Hohfeld, supra note 8, at 36 (arguing that whether a right exists is a matter of "policy" that should be considered "on its merits"); K.N. Llewellyn, The Normative, the Legal, and the Law-Jobs: The Problem of Juristic Method, 49 YALE L.J. 1355, 1359-67 (1940) (exploring the complexity of normative generalization and its relation to the "stuff" of law); see also HANOCH DAgAN, RECONSTRUCTING AMERICAN LEGAL REALISM \& RETHinking PRIVATE LAW THEORY 1 (2013) (reinterpreting legal realism as focusing on several core tensions that need resolution through considered judgment); Joseph C. Hutcheson, Jr., The Judgment Intuitive: The Function of the "Hunch" in Judicial Decision, 25 GA. B.J. 127, 141 (1962) (arguing that intuition plays a crucial role in judicial decisionmaking but not arguing that it is all that matters); Joseph William Singer, Legal Realism Now, 76 CALIF. L. REV. 465, 471-72 (1988) (book review) (arguing that most legal realists see both precedent and legal reasoning as a substantial constraint on judicial decisionmaking).

69. See generally Thomas C. Grey, The Disintegration of Property, in Property: Nomos XXII (J. Roland Pennock \& John W. Chapman eds., 1980). 
theorists like myself argued that we should not use our values to structure property in ways that allocate presumptive control rights and presumptive packages of entitlements. What we have argued is that the structure, shape, and definition of the bundled rights in the property law system must reflect our considered judgments about the legitimate contours of the social order. ${ }^{70}$ We have also argued that presumptive property rights cannot tell us what to do in hard cases; when a plausible argument can be made that a property right should be limited or narrowed to protect competing values, we have no alternative but to give reasons why the case should or should not be distinguished. $^{71}$ All this requires interpretive strategies that use methods of analysis that go beyond the calculation of the best way to lower the cost of coordination among independent actors. In the first instance, it requires placing some types of property arrangements off the table. Some modules cannot be recognized by the law of a free and democratic society no matter how well they reduce the complexity of human interaction.

\section{B. How Many Owners are Consistent with Democracy?}

The Hawaiian island of Lanai is inhabited by only 3,135 people on 141 square miles. ${ }^{72}$ Ninety-eight percent of the land is owned by one man, Larry Ellison, the cofounder of Oracle Corporation. ${ }^{73}$ Originally owned by Native Hawaiians, by the 1870s most of the land had passed to a rancher named Walter Gibson. ${ }^{74}$ In 1922, James Dole, president of what became the Dole Food Company, bought the island and turned it into a huge pineapple plantation. ${ }^{75}$ In the 1980s Dole moved its operations overseas and converted the land use from agriculture to tourism. ${ }^{76}$ In 1985 , the island's ownership passed to Dole's parent company, controlled by billionaire David Murdock. ${ }^{77}$

\footnotetext{
70. See generally ALEXANDER, supra note 49 .
}

71. Singer, supra note 6 , at 1426 .

72. Adam Nagourney, Tiny Hawaiian Island Will See if New Owner Tilts at Windmills, N.Y. Times, Aug. 23, 2012, at A1.

73. $I d$.

74. Kathleen Pender, So What Did Ellison Buy in His Hawaiian Island?, S.F. CHron., June 27,2012 , at D1.

75. Richard A. Hawkins, James D. Dole and the 1932 Failure of the Hawaiian Pineapple Company, 41 HAW. J. HIST. 149, 149-50 (2007); Pender, supra note 74.

76. Nagourney, supra note 72.

77. Id.; Pender, supra note 74; Gary A. Warner, Oracle's Billionaire CEO Purchases Hawaiian Island of Lanai, VANCOUVER SUN, July 17, 2012, at B8. 
Murdock sold the island to Ellison in 2012, retaining the right to construct a field of forty-five-story wind turbines over a quarter of the island. ${ }^{78}$ Because the tourist economy is limited by the difficulties of getting to the island, as well as harmed by the recent economic downturn following the subprime crisis, this development could form the backbone of a more robust local economy, or it could ruin the island's wild beauty—or both. ${ }^{79}$ The plan has sharply divided residents who are also anxious to know how the new development will affect their island. ${ }^{80}$

Why tell this story? First, the most striking thing to an American is the incongruous fact that all the land on the island is owned by one person. The American conception of democracy makes us wince at this. It is reminiscent of the feudal system under William the Conqueror, who reserved the right to take back the land from his lords if they did not do as he wished. ${ }^{81}$ When the Illinois Supreme Court considered the fact that Pullman's Palace-Car Company was the sole owner of the entire town of Pullman, Illinois, it interpreted state law to force the company to sell much of the land. ${ }^{82}$ The court explained that limiting ownership to one company is "incompatible with the theory and spirit of our institutions." ${ }^{, 83}$ Recall that in colonial times, King Charles II gave New Jersey to two lords who sought to install a feudal regime only to face stalwart resistance from the settlers who insisted on freedom from control by a feudal lord. ${ }^{84}$ Their resistance led to the modern American system of wide dispersal of property ownership rather than allowing it to be concentrated in the hands of a small aristocracy. ${ }^{85}$ They also helped establish our tradition of "freehold" property that confers wide powers on owners to control their own land and their own lives rather than being subject to the whim of an absentee lord. ${ }^{86}$

Is there or is there not something untoward or wrong about having one owner of the entire island of Lanai? The idea of minimizing information costs of human interaction does not help us

\footnotetext{
78. Nagourney, supra note 72.

79. Id.

80. Id.

81. See Singer, Infrastructure of Democracy, supra note 55, at WFL11-1 to -2.

82. People v. Pullman's Palace-Car Co., 51 N.E. 664, 668, 677-78 (Ill. 1898).

83. Id. at 674 .

84. Singer, Infrastructure of Democracy, supra note 55, at WFL11-5.

85. See id. at WFL11-5 to -6.

86. Id.
} 
answer this question. In one sense, we can argue that reducing ownership to one minimizes information costs enormously. If you want to use any of the land on Lanai, you have to ask Ellison. The problems of human coordination have been solved; he decides whether you can live on the island, where you can live, and what you can do there. On the other hand, although ownership by one person gives him a great deal of certainty, it creates a great deal of uncertainty to the nonowners who are subject to the owner's whim. Whether they can or cannot do what they want depends on what Ellison decides. Whether they can even live on the island depends on what he thinks of them. If our goal is to minimize the costs of information for each individual, we need to give each person some basis for making plans; that suggests ensuring that each person has some property she is entitled to use as she pleases. How many land owners do there need to be for this to be true? What rights do tenants and nonowners need to have so that they have some opportunity to become owners or so that they have sufficient freedom to make their own choices about how to live? If each person is entitled to equal protection of the law, and if that means that we need to promote equal opportunity, what property law architecture is necessary to achieve that set of values? How many owners is enough? What is the appropriate balance of rights held in fee simple versus leasehold versus condominium status? Would it promote or violate property rights to take the land from Ellison and redistribute it to the thousands of islanders?

Americans do not all agree about the number of owners or the mix of property forms that comports with our commitment to treating each person as entitled to life, liberty, and the pursuit of happiness. Nor do we all agree about the contours of the property system that shape our choices. We have abolished feudalism, but we still have islands owned by one person, and the fact that Americans deeply value the ideal of dispersed property ownership does not mean that inequality is not an issue for us today. On the contrary, the Occupy movement placed on the national agenda the increasing inequality of wealth and income over the last thirty years. ${ }^{87}$ The value choices here are front and center. Though some argue that we should desist from

87. $C f$. Donald L. Barlett \& James B. Steele, The Betrayal of the American Dream 10-11 (2012); Peter Edelman, So Rich, So POOR: Why IT'S So HARd To END

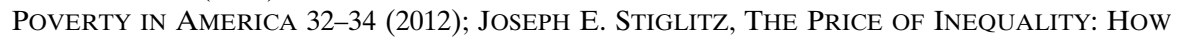
TODAY's DIVIDED SOCIETY ENDANGERS OUR FUTURE 246-47 (2012). 
"class warfare" and that it is wrong for people to be "envious" of those who are successful, others argue that inequality not only harms the economy but also contradicts the American ideal of equal opportunity. ${ }^{88}$

When slavery was abolished, decisions needed to be made about who would own the plantations upon which the slaves worked. ${ }^{89}$ A decision could have been made to transfer ownership to the former slaves either in individual lots or in a corporate or collective form. The slaveowners who rebelled against the United States could have forfeited their property rights in the land. None of these things happened. The rebels who pledged loyalty to the United States got to keep their lands, and over time, less and less was done to help the former slaves. ${ }^{90}$ They received neither back wages nor land of their own. ${ }^{91}$ What should have been done?

Economizing on information costs tells us little or nothing about what to do here. Information costs are low whether we give the plantation to the former slaveowner or the former slaves. Perhaps they are lower if we give the land to the former slaveowner because then we have one owner rather than many. As I have noted, we could lower information costs about who controls property even further by giving all the land there is to one person-as actually occurred when William conquered England and was crowned king on Christmas day in $1066 .{ }^{92}$ Of course, giving one person ownership of all the land increases some transaction costs; if everyone in the land wants access to it, then the king has a lot of meetings to take, and the costs of managing all those requests will be quite burdensome on him and on everyone else who is, in the meantime, excluded from the things they

88. See STIGLITZ, supra note 87, at 17 ("Belief in America's essential fairness, that we live in a land of equal opportunity, helps bind us together.").

89. See Aviam Soifer, Status, Contract, and Promises Unkept, 96 YALE L.J. 1916, 1938-40 (1987) (describing ambivalence about how to protect former slaves and their property rights in the wake of the Civil War).

90. See id. at 1939-45 (describing how plans for federal guardianship and land redistribution for former slaves yielded to the abandonment of redistribution plans in favor of leaving lands to Confederate owners).

91. See Rhonda V. Magee, Note, The Master's Tools, from the Bottom Up: Responses to African-American Reparations Theory in Mainstream and Outsider Remedies Discourse, 79 VA. L. REV. 863, 890-91 (1993) (describing the failure of Reconstruction land-redistribution and reparation efforts).

92. MARC Morris, The Norman CONQuest 166, 196, 198 (2012). King William immediately allowed property rights to become more complex by creating a feudal system based on specific personal relationships and obligations. See id. at 202 (describing the distribution of King William's enemies' lands after he became England's new ruler). 
need. So perhaps there is an efficient balance between information costs and transaction or management costs. The point, however, is that costs of managing the system are not the only thing we care about. We are interested in the distribution of property not only because we care about satisfying our preferences at the lowest possible cost but also because we care about how many people's preferences get satisfied. More than that, we care about whether we are living in a democratic or a feudal society, whether we will have freedom or servitude, and whether we will have equal status before the law or titles of nobility.

Consider the continuing dilemmas in South Africa, where the antiapartheid constitution both granted a fair amount of protection to existing property owners and authorized land reform and common law development needed to move from an apartheid society to a free and democratic one. ${ }^{93}$ Continuing choices need to be made that reflect not only pragmatic economic and political needs and realities but also fundamental value choices. The one thing that cannot be assumed is that all "established property rights" must be protected; that would be a recipe for servitude. Recall the idea that property makes liberty possible. As Professor Jeremy Waldron has explained, everything that is done must be done somewhere, and one cannot do anything unless one has a place to do it. ${ }^{94}$ Virginia Woolf famously argued that women could not write novels until they had a room of their own. ${ }^{95}$ If the system of property law does not make it realistically possible for each person to become an owner of the property needed for a full human life, then we have deprived individuals of the freedom that was the reason for creating property rights in the first place. In a society that has chosen to reject apartheid as a way of life, property rights must not only be redistributed but also tailored to enable equal liberties to emerge. $^{96}$

The question of how much inequality is appropriate cannot be answered by quantitative or economic analysis alone; rather, it implicates the meaning of the values of liberty and equality. It engages choices about the contours of a free and democratic society.

93. See, e.g., A.J. VAN DER WALt, PROPERTY In THE MARgins 1-26 (2009) (exploring the dilemmas of property rights in a transformative society seeking to abolish apartheid).

94. Jeremy Waldron, Essay, Homelessness and the Issue of Freedom, 39 UCLA L. REV. 295, 296 (1991).

95. Virginia WoOlf, A RoOM OF OnE's Own 4 (Harvest ed. 1989) (1929).

96. See Joseph William Singer, Property and Equality: Public Accommodations and the Constitution in South Africa and the United States, 12 S. AFR. J. PUB. L. 53, 54-55 (1997). 
Conservatives suggest that property redistribution is anathema because property is the basis of liberty; on that view, taking property inevitably takes liberty. But liberals argue that if property is necessary for the exercise of liberty, then denying property ownership denies the ability to exercise liberty; on that view redistribution may be required to promote freedom. Determining whether our system generates sufficient opportunities to acquire property (or the abilities that property enables) implicates normative questions that can only be answered by reference to analysis of the fundamental values of freedom, equality, and democracy.

\section{Who Can Own Property in a Democracy?}

The Fourteenth Amendment ensures "equal protection of the laws," "97 and the Civil Rights Act of 1866 ensures that every citizen shall have the same right to purchase and own property as is enjoyed by white citizens. ${ }^{98}$ The Public Accommodations Law of 1964 ensures equal access to certain public accommodations without regard to race. ${ }^{99}$ The 1968 Fair Housing Act prohibits the creation of racial covenants as well as racially discriminatory refusals to sell or rent or mortgage property because of race, religion, or national origin. ${ }^{100}$ And the case of Shelley v. Kraemer ${ }^{101}$ interpreted the Equal Protection Clause to allow owners to create racially restrictive covenants but denied them the power to enforce them in court. ${ }^{102}$ All these laws and decisions have embodied an antiapartheid principle at the heart of modern American property law; no one can be denied the opportunity to acquire or enjoy property because of the color of their skin. ${ }^{103}$ We tend to take these laws for granted in 2014, but the abolition of racial restrictions on access to property occurred in my lifetime. And although the married women's property acts of the nineteenth century ensured that married women could own and control their own property ${ }_{104}$ it was not until the 1960 s that equitable distribution statutes ensured women in separate property states a

97. U.S. CONST. amend. XIV, § 1 .

98. Civil Rights Act of $1866 \S 1$, 42 U.S.C. $\$ 1982$ (2006).

99. Civil Rights Act of $1964 \S 201,42$ U.S.C. $\$ 2000$ a (2006).

100. 42 U.S.C. $\$ \S 3601-3619$.

101. Shelley v. Kraemer, 334 U.S. 1 (1948).

102. Id. at $13,22$.

103. See generally Singer, Anti-Apartheid Principle, supra note 55.

104. SINGER, supra note $33, \S 9.2 .2$, at 392-93. 
share of the marital property accumulated during marriage upon divorce. ${ }^{105}$

The question of who is entitled to own property is not limited to issues of discrimination. Consider the tenants who are evicted when their landlords lose their properties to foreclosure after defaulting on subprime mortgages. Should rent-paying tenants have any rights to stay in their homes? The law has traditionally said no because tenants are not owners and the new owners have the right to end periodic tenancies upon giving requisite notice. ${ }^{106}$ But recall that homeowners were also originally not owners when they borrowed money in exchange for a mortgage on their property. Some states-like the Commonwealth of Massachusetts-retain this old-fashioned system. When you grant a mortgage to a bank in Massachusetts, the bank has title to your property until you pay off the note. ${ }^{107}$ Similarly, states that use deeds of trust rather than mortgages grant title to the property to the trustee until the debt is paid. ${ }^{108}$ Despite the fact that the borrower gave the property title to the lender in exchange for the loan and the borrower then defaulted on the loan in violation of the agreement, the equity courts in England intervened to protect the rights of nonowners from strict foreclosure, allowing them to stay on land they did not "own," even though they had defaulted on their obligations, as long as they paid off the debt in a reasonable time. ${ }^{109}$ So too do statutes in most states, which give homeowners the right to stay in their homes and avoid foreclosure if they can make up the payments they have missed in a timely fashion. ${ }^{110}$ These protective rights exist even though the mortgaged homeowners in states like Massachusetts do not have title to their homes and even though they have missed payments they solemnly promised to make.

Why then do not tenants who are paying the rent have the same rights to stay in their homes after foreclosure, especially when the new owner is a bank that has no interest in moving into the home

105. Id. \$ 9.3.1, at 394-95.

106. See id. $\$ 10.5 .4$, at 467-68.

107. See, e.g., Adam J. Levitin, The Paper Chase: Securitization, Foreclosure, and the Uncertainty of Mortgage Title, 63 DUKE L.J. 637, 665-66 (2013) (describing mortgagee possession of land title in title-theory states); id. at $692 \mathrm{n} .232$ (citing United States Bank National Ass'n v. Ibanez, 941 N.E.2d 40 (Mass. 2011), for the proposition that mortgage transactions are considered a sale and repurchase of land in title-theory states such as Massachusetts).

108. SINGER, supra note $33, \S 11.5 .1$, at 561.

109. Id. at 557-58.

110. SINGER, supra note $33, \S 10.4 .4 .1$, at 456 . 
itself? In the mortgage context, we deem the bank's interest to be only in the repayment of the debt with contractually agreed-upon interest, whereas the homeowner's interest is a personal attachment to the home, deserving of solicitude regardless of what the contract says. As long as the bank is made whole monetarily, mortgage law gives the homeowner the right to stay in her home. Why are residential tenants denied this right? Several jurisdictions have in fact granted tenants the right to remain in their homes unless the landlord can show a legitimate reason to evict them, such as the landlord's interest in moving into the property herself. ${ }^{111}$ Massachusetts recently passed statutes that allow rent-paying tenants to continue to live in their homes even after foreclosure if the property is bought at foreclosure by the mortgagee-bank, as often happens. ${ }^{112}$ Under these laws, only when the property is transferred to a third-party owner is the tenant vulnerable to eviction. ${ }^{113}$ Most states, however, conceptualize tenants as nonowners who have no right to continue living in their homes once the lease runs out, no matter how long they have been living there. ${ }^{114}$

Should tenants have a right to continue living in their homes unless just cause can be shown to evict them? Should tenants be treated as the "owners" of their leaseholds with landlords relegated to a subordinate status as future interest holders who can kick out tenants only if the landlords want to occupy the property as their home? Should rent-paying tenants be empowered to stay in their homes after foreclosure unless the new owner can demonstrate a superior interest? Answering these questions requires us to choose the kind of social life we want to have. It requires determining whether there is a relevant distinction between defaulting homeowners and rent-paying tenants. It requires a normative analysis of the relevant interests, values, and rights at stake and the justifiability of the expectations of the parties. It requires us to

111. E.g., D.C. CODE $§ 42-3505.01$ (2001 \& Supp. 2013); N.J. STAT. ANN. §§ 2A:18-61.1 to .3 (West 2000 \& Supp. 2013); see also SINGER, supra note 33, § 10.5.4, at 468. New Hampshire also limits eviction in certain circumstances. N.H. REV. STAT. ANN. §§ 540:1-a, 540:2 (LexisNexis 2006 \& Supp. 2013)

112. MASS. GEN. LAWS ch. 186A, §§ 1-6 (2011).

113. See id. $\S 2$ ("[A] foreclosing owner shall not evict a tenant except for just cause or unless a binding purchase and sale agreement has been executed for a bona fide third party to purchase the housing accommodation from a foreclosing owner.").

114. See SINGER, supra note 33, § 10.5.4, at 467-68 (observing that landlords in states without strict antieviction laws are "generally free to refuse to renew existing leaseholds"). 
determine the value we place on staying in one's home. All this requires something deeper and more fundamental than an analysis of cost minimization.

\section{How Long Do Property Rights Last in a Democracy?}

In college, I took an introductory economics course with Professor Randall Bartlett. In one of the early classes, he asked us if we were in favor of economic competition. Having been taught that competition was a good thing, we all said yes. He looked at us and said, "Really? Would you like it if you never knew, when you came to class, whether or not there might be someone else already sitting in your seat, ready, willing, and able to do a better job than you?" Well, no that would be nerve-wracking, we all thought. That would be like going home and finding someone else in your bed, as Doctor Zhivago did when he came home to find dozens of people living in his mansion. ${ }^{15}$ We all would like to know that we have a home to go home to; we would all like to know we have a seat in the class-at least until the final exams come around. Professor Bartlett did not put it in these words, but as a property scholar, I know now that what we valued was property. We wanted a stable basis of expectation, even if that stability was temporary. We wanted a haven from the storm, time to learn, time to take advantage of the opportunity that college was.

Of course, it is not a foregone conclusion that a property law system should give us such peace of mind. I played violin in orchestras when I was a teenager, and some of them were competitive to get into. Auditions not only determined if you got into the orchestra but also what your seat was. And more than that, at any time, one of the violinists sitting behind you in the orchestra could challenge you to an audition to see if they could take your seat from you. You never knew, from day to day, whether someone would challenge you, play better than you, and take your seat, demoting you to a less prestigious perch. You might even be challenged by someone in the junior orchestra-a challenge with the real potential for a dramatic fall from grace. One could imagine an even more dramatic competitive system that would allow anyone-even an outsider-to compete at any moment for your seat in the orchestra. Nor is this a far-fetched notion. Few Americans have job tenure; the American system of at-will employment means that most people can be fired at

115. Doctor ZHIVAGO (Metro-Goldwyn-Mayer 1965). 
any time for any (nondiscriminatory) reason. And recent changes in the economy have turned many more of us into independent contractors who have even less job security than the typical employee.

Our property law system, on the other hand, does not usually work this way. Usually our property cannot be taken away from us just because someone else thinks they can use it better or need it more. If you want to buy my house, you can approach me with an offer, but I am entitled to refuse without giving you a reason. I do not have to justify myself to you. In particular, I do not have to prove I can use the property better and more efficiently than you or that I value it more than you do. And you cannot force me to sell my property to you no matter how badly you want it or how valuable the use you want to put it to. Perhaps one could argue that giving me the power to exclude others from my property and to decide when, if ever, to relinquish my rights minimizes the costs of figuring out what can done with the property. It certainly seems as if that would be the case, at least as compared with allowing judges to make case-by-case determinations of who is the best user of the land. But the point I want to make is that this choice is not only a choice about cost minimization; it is a value choice among forms of social life. Do we want to organize things so you have a seat in the class with the right to graduate if you follow the rules and do the work successfully, or would we rather treat you like a day laborer or an independent contractor who has to prove yourself from moment to moment, constantly at risk of losing your spot in a class?

Nor is the possibility of conditional property entirely foreign to American law. In fact, multiple legal regimes embrace conditional property ownership. Recall that some federal lands sold by the United States through the nineteenth-century homestead laws were conditioned on the buyer building a home on the land and working it. ${ }^{116}$ Congress decided that the land was better used by settlers than by speculators, and so Congress conditioned ownership on that basis. ${ }^{117}$ The relative hardship doctrine allows you to force me to sell my land to you if you build a structure that encroaches on my property when you thought in good faith that that property belonged

116. LAWrence M. Friedman, A History of AMERICAN LAW 416 (2d ed. 1985) (describing the Homestead Act of 1862).

117. The Homestead Act of 1862 made title conditional on the owner improving the land. Act of May 20, 1862, ch. 75, § 2, 12 Stat. 392, 392 (repealed 1976). 
to you and I failed to do anything to stop you from building. ${ }^{118}$ You can take my property by adverse possession if you occupy it for a long time without my permission. ${ }^{119}$ Sometimes the courts will even force you to sell me the benefit of a covenant you own if it interferes with the best and highest use of my property. ${ }^{120}$ The state of Hawaii forced landowners on the island of Oahu to sell their property to their tenants because the distribution of property was so unequal that it deprived almost everyone of the chance of becoming an owner. ${ }^{121}$ And remember that the fair use exception to copyright law prevents you from interfering with my freedom to comment on your intellectual property. ${ }^{122}$

In all these cases, lawmakers faced a choice between property and competition, between stability and change, between quiet enjoyment and new development. How much stability do we want and how much competition do we want? How much power should owners have to stop others from impinging on the value of their property? What obligations do owners have to the community and their neighbors? Property law systems must take positions on how much stability and how much competition to foster. Indeed, at the time of the American Revolution, it might well have been thought to be a violation of property rights for someone to open a rival store in a small town. ${ }^{123}$ It took a decision of the Supreme Court in the Charles River Bridge case ${ }^{124}$ to cement the idea in American law that there was no property right to be free from ordinary competition. ${ }^{125}$ It took a decision by the Supreme Court of Illinois to force the Pullman Company to sell its property in Pullman, Illinois on the grounds that

118. SINGER, supra note $33, \S 2.4 .1$, at $41-42$.

119. Id. $\S 4.2$, at $143-55$.

120. See, e.g., Blakeley v. Gorin, 313 N.E.2d 903, 913-14 (Mass. 1974) (holding that enforcement of restrictions preventing construction of an apartment hotel complex would "tend to impede reasonable use of the land for purposes for which it is most suitable" and require owners of nearby lots to accept damages).

121. Haw. Hous. Auth. v. Midkiff, 467 U.S. 229, 232-33, 245 (1984).

122. 17 U.S.C. $\$ 107$ (2012).

123. Cf. Morton J. Horwitz, The Transformation in the Conception of Property in American Law, 1780-1860, 40 U. CHI. L. REV. 248, 248 (1973) (describing the transformation from a static conception of property based on protecting established uses to a dynamic one that viewed competition as desirable even if it resulted in harm to previously established property rights).

124. Charles River Bridge v. Warren Bridge, 36 U.S. (11 Pet.) 420 (1837).

125. See generally Stanley I. Kutler, Privilege and Creative Destruction: The CHARLES RIVER BRIDGE CASE (1971). 
company towns were contrary to the "spirit of our institutions." Choosing how many owners is enough and how much stability to protect are not only choices about the costs of determining how to use property and who gets to decide that. Rather, they are also choices about the nature of social and political life-choices that depend on normative reasoning about what it means to protect the freedom of individuals, to treat each person with equal concern and respect, and to live in a free and democratic society.

\section{E. What Obligations Do Owners Have in a Democracy?}

To the chagrin of the mayor, for many years there has been a gaping hole in downtown Boston. ${ }^{127}$ Filene's Department Store closed, and the building was purchased by an owner who razed the building. ${ }^{128}$ Then the subprime crisis struck, and the new owner either could not or would not redevelop the property. ${ }^{129}$ This left an ugly, empty lot in the midst of the downtown area-an eyesore that remained for several years, affecting the entire environment of the downtown area. ${ }^{130}$ The hole in the ground affected the surrounding area by depriving the neighbors and the community as a whole of the benefits of the business and housing that could have been profitably constructed on the property. The mayor and other city officials did whatever they could to convince the owner to develop the property, to no avail. ${ }^{131}$ The most valuable use of the property to the owner may have been to leave it vacant and wait for the market value of the property to appreciate or for the economy to recover from the Great Recession; development may also have been contingent on banks recovering from the subprime debacle so that they would be willing to loan the money necessary for the development. Perhaps the city could have taken the property by eminent domain and transferred it to an owner who would develop it rather than wait for market conditions to

126. People v. Pullman's Palace-Car Co., 51 N.E. 664, 674 (Ill. 1898).

127. Thomas Grillo, Stalled Filene's Project Poised for Rebirth, BBJ REAL EST. DAILY (June 12, 2012, 9:32 AM), http://www.bizjournals.com/boston/real_estate/2012/06/filenes-projectpoised-to-be-reborn.html.

128. Abby Goodnough, A Downtown Hub Is Missed, and a Replacement Is Stalled, N.Y. Times, Sept. 12, 2010, at A20.

129. Greg Turner, From Basement to Tower: Condos, Shops Eyed for Downtown Crossing, Bos. HeRALD, June 12, 2012, at 4.

130. Jenn Abelson, Bostonians Dream Big About a Reborn Downtown Crossing, Bos. GLOBE, Feb. 19, 2012, at G1; Turner, supra note 129.

131. Paul McMorrow, The Art of the Deal, Boston-Style, Bos. GloBE, Feb. 7, 2012, at A13. 
improve. ${ }^{132}$ Of course, this would raise all the flags stirred up by the Kelo v. City of New London ${ }^{133}$ decision. Taking the property would be unconstitutional in many states despite the externalities of the empty lot, ${ }^{134}$ whereas in other states the taking would only be lawful if an empty lot constitutes a form of "blight." right to leave the lot empty or not when it could be profitably developed? Does the city have the power to take the property by eminent domain to transfer it to an owner who will develop it?

Professor Henry Smith is quite right that as a structural matter, we start from the presumption that there is an owner with the right to exclude others and the power to use (or not to use) the property. ${ }^{136}$ $\mathrm{He}$ is also right that we sometimes address this issue through "governance" strategies by equitable rules. ${ }^{137}$ Such rules may require the property to be developed or transferred, or they may force the property to be redistributed from a recalcitrant owner to one who will develop the property in a manner consistent with the public interest. But answering the question of whether the owner has any obligations not to leave an empty lot in the downtown area during a recession is not one that can be answered only by reference to the structural logic of property, the economics of information costs, or the costs and benefits of particularized decisionmaking.

The problem here is not information costs. If you are not the owner and you want something to happen on the empty lot, talk to the owner. If you are the owner, you are free to use or not to use the property and you do not have to explain yourself to anyone-even the mayor. Information costs are low here. The problem implicated is a normative question about whether the owner was legitimately

132. Indeed, Mayor Thomas M. Menino threatened to seize the site by eminent domain, before ultimately providing tax credits to Millennium Partners, which bought the property in April 2013. Thomas Grillo, Menino Defends Filene's Tax Credits for Millennium Partners, BBJ REAL EST. DAILY (Sept. 9, 2013, 3:22 PM), http://www.bizjournals.com/boston/real_estate/2013/ 09/menino-defends-filenes-tax-credits.html.

133. Kelo v. City of New London, 545 U.S. 469 (2005).

134. See id. at 489 (“[M]any States already impose 'public use' requirements that are stricter than the federal baseline.").

135. For example, in California, cities may only take land deemed "blighted" for economic development purposes. See CAL. HEALTH \& SAFETy CODE $§ 33037$ (West 2010).

136. See Smith, supra note 7, at 1693-94 (arguing that "[t]here is no interest in exclusion per se," but that "exclusion strategies, including the right to exclude, serve the interest in use," and that "property defines things using an exclusion strategy of 'keep off' or 'don't touch' and then enriches the system of domains of owner control with interfaces using governance strategies").

137. Id. at 1715 . 
exercising his property rights or whether he was unjustifiably imposing harms on the community by his inaction. Was this an instance of a legitimate exercise of an owner's rights, or was this an instance of an owner imposing negative externalities on everyone else in the city, jeopardizing their property rights and their livelihoods? The question was not how to structure property rights to reduce the complexity of human interaction; the question was whether the owner had the right to decide by himself to create a crater in the heart of the downtown area and stubbornly keep it there for years, or conversely, whether the city had the power to interfere with the owner's freedom to choose what, if anything, to do with his own property. Was this a case of an individual freely and rationally exercising his legitimate property rights, or was it a case of an individual acting to batter and damage the property rights of others?

Smith correctly explains that property law organizes land in a way that assigns ownership of bundled rights to individuals or corporations and then creates presumptions that grant those owners presumptive control of the property. ${ }^{138} \mathrm{He}$ is also right that we limit the rights of owners in particular classes of cases when the exercise of property rights harms the rights of others or undermines the social network. ${ }^{139}$ But Smith wrongly concludes from this that governance strategies represent a gloss on a core exclusion strategy. ${ }^{140}$ The question of whether an owner has the right to be free from expropriation of his property for transfer to others is not just a matter of "singl[ing] out" particular cases for "special treatment."141 It embodies fundamental normative choices about the powers that go along with ownership in a free and democratic society. It asks us to address the constitutional question of whether property can be taken from one owner for transfer to another.

Libertarians who adopt Professor Robert Nozick's perspective would probably argue that owners should not have to sacrifice their property for the good of the community when the community wants

138. See id. at 1709-13 (discussing control and arguing that "the basic features of property are not sticks, but automatic, presumptive features of an exclusionary modular strategy").

139. See id. at 1713-16 (discussing equitable safety valves in the context of nuisance law and exclusion strategies).

140. See id. at 1710 ("[G]overnance strategies-implemented by nuisance law, covenants, and regulations-take exclusion as a platform and modify its features when it is important to do so.").

141. See id. at 1710 ("At some cost, specific people in the large and indefinite set of in rem duty bearers can be singled out for special treatment."). 
to transfer the property from A to B. ${ }^{142}$ If the city wants the property badly enough, it should offer the owner enough to induce him to sell; if he refuses, then he is not only within his rights but also values the property more than others do. Of course, the problem is more complicated than this. Even Nozick worried about the case of the sole owner, arguing that someone who comes to own the only water hole in the desert should have obligations to share the water with everyone else. ${ }^{143}$ Ownership, with the attendant right to exclude others, confers power on the owner-power to deny other people things they need to live. ${ }^{144}$ Granting the owner veto power over the decision whether to keep an empty lot in the middle of Boston's Downtown Crossing arguably violates democratic norms by giving despotic power over the community to a single individual. This situation approaches lordship. Our property norms coexist with democracy as a form of political governance; problems can arise if property rights allow the few to impose their will on the many.

Liberals would similarly debate the appropriate resolution of this problem. Liberals worry that majorities are likely to deprive powerless working class or poor homeowners of their homes to transfer them to large corporations or that majorities may decide to gentrify a community and displace and disperse a minority enclave. If only blighted property can be taken and redistributed, then the poor are vulnerable to having their property taken, but the rich are not. How is this compatible with equal protection of the law? On the other hand, one could classify the vacant lot as blighted because it impacts the local economy and is a visual and environmental blot on the center of commerce. Owners have no right to use their property to harm the property rights of others. They have no right to impose their will on the community. We live, after all, in a free and democratic society, and we do not abide lords who impose their will on the rest of

142. See Robert Nozick, AnArChy, StATE, And Utopia 160-65, 180 (1974) ("By what process could such a transfer among two persons give rise to a legitimate claim of distributive justice on a portion of what was transferred, by a third party who had no claim of justice on any holding of the others before the transfer?").

143. See id. at 180 .

144. See LAUra S. UnderkufFler, The IdeA of Property: Its MeAning ANd Power 89-90 (2003) (discussing the right to exclude and the power it confers in cases such as those involving valuable commodities); Laura S. Underkuffler-Freund, Property: A Special Right, 71 Notre DAME L. REV. 1033, 1039 (1996) (explaining how granting a property right to one person confers power over others by "necessarily and inevitably den[ying] the same right to others"); $c f$. Waldron, supra note 94, at 299-301 ("As far as being on private property is concerned ... the homeless person is utterly and at all times at the mercy of others."). 
us. As with the libertarian debate, liberals need to come to terms with the conflicting interests and values at stake here, including the property interests of the owner and of the neighbors who have an interest in a vibrant downtown area where they can congregate, do business, and find pleasure.

So is the owner here exercising his legitimate property rights, or is he imposing harm on the community? Does he have the right to put his own interests above those of the community, or does he have an obligation either to develop his property or submit to a taking by eminent domain for transfer to someone who will develop it? These questions require normative choices among conflicting values; they also require us to interpret the meaning of those values. Would it deprive the owner of equal protection of the law to take his property because we think others could use it better, or does the owner's refusal to develop the property constitute an inegalitarian exercise of power that deprives other owners of the value of their property? Would a taking by eminent domain violate equality norms or promote them? Would it deprive the owner of the liberty to use his property as he wishes, or would it protect the quiet enjoyment of neighboring property owners by abating a nuisance? These questions implicate not only common law doctrines but also constitutional norms. They represent not just special treatment of particular cases, but choices of fundamental structural norms and a decision about our way of life. They represent choices about the relation between rights and power.

In a free and democratic society, owners have rights, but they also have obligations. Restaurants and shops cannot exclude patrons on the basis of their race or religion. ${ }^{145}$ Nor can public accommodations refuse to make reasonable accommodations to make their services available to persons with disabilities. ${ }^{146}$ Owners are not free to ignore longstanding occupation of their property if they want to protect themselves from loss of their property by adverse possession. ${ }^{147}$ Owners cannot vote to pass zoning laws that unduly inhibit the ability of religious institutions to operate in their communities. ${ }^{148}$ Landlords cannot fail to provide tenants with heat or

145. 42 U.S.C. $\$ \S 2000 a-2000 a-6$ (2006); SINGER, supra note 33, § 2.6.1, at 45-48.

146. SINGER, supra note $33, \S 2.6 .3$, at $65-68$.

147. Id. $\$ 4.1$, at $140-43$.

148. Id. $\S 13.7 .1 .3$, at $662-64$. 
hot water. ${ }^{149}$ Owners are not free to interfere with the quiet enjoyment of neighboring owners, ${ }^{150}$ nor are they free to saddle buyers with covenants that unreasonably impede the alienability of land. ${ }^{151}$ Owners are not free to sell property without reducing the transaction to writing and recording the documents in the registry of deeds. ${ }^{152}$ Nor are they free to build without complying with local building and construction codes. ${ }^{153}$ The number of obligations the law imposes on owners is far too numerous to mention. And determining what obligations owners have requires attention to our deepest norms and values.

Property law is designed to spread freedom, opportunity, security, and wealth, but it is also designed to prevent owners from inflicting harm on others and from acting in a manner that is incompatible with norms of propriety. Condominium associations, for example, are empowered to pass reasonable rules governing the use of units as well as common areas, and condominium owners are subject to those rules. ${ }^{154}$ But the law places limits on the kinds of rules that can be passed. Those that interfere too much with individual freedoms will be deemed outside the lawful authority of the association. For example, rules that prevent owners from displaying religious symbols on their doors may be prohibited because they violate fair-housing laws that protect religious minorities from being excluded from housing. ${ }^{155}$ The issues that can come up in this context and others like it are almost limitless. Can condominium associations prohibit smoking entirely both in common areas and inside units? Can they prevent owners from posting signs indicating support for political candidates? Can universities prohibit students from posting political signs on their dorm windows? The Confederate flag? The Swastika? Can shopping centers exclude patrons wearing "Peace on Earth" t-shirts? Obama t-shirts? Defining the scope of property rights means defining the rights and obligations of persons in a free and democratic society.

149. Id. $\S 10.6 .3$, at $472-76$.

150. Id. $\$ 3.1$, at $98-100$.

151. Id. § 6.7.2, at $278-83$.

152. Id. § 11.3 .2 , at $506-08$.

153. Id. § 13.6.1, at $652-53$.

154. Id. \& 8.5, at 375-76.

155. Bloch v. Frischholz, 587 F.3d 771, 772-73 (7th Cir. 2009). 


\section{PROPERTY, POLITICS, AND MORALITY}

Suppose we want to think about the basic structure of property law. Instead of turning to economics, what would happen if we start by looking to political and moral theory instead? What would this tell us about the basic structure of property law? It would require us, before we do anything else, to choose among political regimes, such as dictatorship, monarchy, aristocracy, feudalism, communism, tribalism, corporatism, and democracy, among others. We would first have to acknowledge basic values that the system should reflect. Property scholars sometimes forget to do this because we operate within a normative and political framework that we take for granted; we live in a democracy, and that means we have made a commitment to a certain type of polity. At the same time, we have multiple and conflicting interpretations of the basic values that a democracy should uphold.

Hard as it may be to articulate what democracy means, we can get some traction by looking to the things democracies reject. If we look to our own history as colonies of Great Britain and our own experience with the institution of slavery, it becomes evident that we have rejected monarchy, feudalism, established religion, and slavery as forms of social life and as political systems. This also means we reject those ways of organizing control over property. Though all this may seem obvious, it actually exacts substantial constraining force on us in defining the type of property law system that is compatible with our way of life. What does it mean for us today that we reject monarchy, established religion, feudalism, and slavery? What are the basic values of free and democratic societies? Arguably the most important values we hold are liberty, equality, and government of the people, by the people, and for the people.

We start before all else from the premise that each human being is equal. ${ }^{156}$ We reject the idea of unequal status. ${ }^{157}$ We have no lords in America. Indeed, the Constitution contains a Nobility Clause that prohibits Congress from granting any title of nobility. ${ }^{158}$ We do not need to look to the Fifth or Fourteenth Amendment to find an equality principle at the heart of the Constitution. Just as we have no

156. THE DECLARATION OF INDEPENDENCE para. 2 (U.S. 1776).

157. U.S. CONST. amend. XIV, $\S 1$.

158. Id. art. I, § 9, cl. 8 ("No Title of Nobility shall be granted by the United States ...."); see also id. art. I, § 10, cl. 1 (prohibiting the states from "grant[ing] any Title of Nobility"). 
lords, we have no masters. The Nobility Clause, ${ }^{159}$ the Fourteenth Amendment's Equal Protection Clause, ${ }^{160}$ the Thirteenth Amendment's abolition of slavery, ${ }^{161}$ and the Fourteenth Amendment's guarantee of due process of law $^{162}$ all teach a single lesson. Each person is entitled to equal concern and respect. Part of what that means is that each person is equally entitled to freely determine her own destiny. We, each of us, have rights to life, liberty, and the pursuit of happiness. No one can tell us what path we should take, what job we must have, where we must live, or how we must spend our days. We have individual liberty to decide how to live our lives. We are free to adopt and live by the religious and moral values that come to us or that we have chosen. And because we believe that each human being is "created equal," we are not free to deny others the liberties we demand for ourselves.

Of course, as Professor Henry Smith argues, this poses a coordination problem. ${ }^{163}$ But it also poses both a moral problem and a political problem. How can the free actions of each be made consistent with the free actions of all? This is the basic problem moral and political theorists analyze. Equal freedom can be achieved only if freedom of action is limited to ensure that one person's actions do not impair the legitimate rights of others to equal freedom. And if Professors Jeremy Waldron and Laura Underkuffler are right that we are only free to act if we have somewhere to engage in the action, ${ }^{164}$ then freedom requires property to be distributed in a manner that gives each and every person a place where she is entitled to be and sufficient resources so that she is able to sustain life and to pursue happiness. If we adopt democracy as a political system, we will want to give individuals freedom to adopt and live by their own moral codes as long as those codes are consistent with the ability of others to live by their moral codes. We need both space for moral principles and space for political principles that enable people with differing religious and moral views to coexist together. We differentiate moral reasoning from public or political reasoning to some extent, at least if we assume that we are going to live in a society with plural

159. Id. art. I, $\S 9$, cl. 8 .

160. Id. amend. XIV, $\S 1$.

161. Id. amend. XIII, $\S 1$.

162. Id. amend. XIV, $\S 1$.

163. See supra note 24 and accompanying text.

164. See supra note 144. 
"comprehensive philosophical moral doctrines" as Professor John Rawls called them. ${ }^{165}$ We need reasons for laws that could be acceptable to persons with very different world views, values, religious creeds, and perspectives.

What this means is that we face more than a coordination problem; we face the problem of interpreting the values of liberty, equality, and democracy and resolving conflicts that may arise among them. Though the values of liberty and equality may appear to be "self-evident," their interpretation is not. I may be free to choose my friends on the basis of race, but I am not entitled to choose my customers or tenants on that basis; owners of residences may choose whom to invite to dinner on any basis they like, including a racist one, but owners of restaurants may not engage in similarly discriminatory choices in determining whom they allow into their establishments. I may be free, with others, to create a homeowners' association, but our collective powers must be limited to ensure that the majority of owners do not oppress the minority or interfere unduly with the freedom of each owner to control her own unit so that she can have a place to live her life in peace.

In addition to basic values of liberty and equality, we believe in democratic, representative government with elected officials empowered to pass laws and regulations that enable us to live together in peace and that promote the common welfare. That means that we want to be governed by representatives chosen by the people through elections and not experts chosen by the American Economic Association or the American Philosophical Association. It means we do not have an established church. This does not mean we do not see a place for experts or religion; it means they are not the sole determinants of social values or the norms that underlie and justify our laws. Experts have expertise in particular subject matter areas, but they are not the last word on what the laws should be. Religions are the source of many of our deepest values, but we do not hand government over to religious institutions. Democracies believe in selfgovernment, and that means that the people, in some way, adopt our own laws, including rules governing the distribution and exercise of property rights. We want to be able to use our property as we wish, but we also want to be able to collectively choose laws that protect our property rights from things our neighbors might do next door.

165. John Rawls, Justice As FAIRness: A Restatement $§ ~ 5.2$, at 14 (Erin Kelly ed., 2001). 
Legitimate zoning laws do not take away our property rights; they ensure that our property rights are protected. They may limit the freedom of individual owners to do what they wish, but they express the freedom of the majority to limit property uses to ensure that we can have quiet enjoyment of our own property in a municipal environment that is diverse, sensible, and attractive.

Choosing to live in a free and democratic society that treats each person with equal concern and respect has enormous consequences for the basic structure of property law. But what those consequences are differs depending on one's normative framework. As I have noted, the ideals of equality, liberty, and democracy are not selfdefining. They require interpretation of our most fundamental values. A libertarian framework such as that presented by Nozick will interpret these basic values far differently than a liberal framework that uses the approach of Rawls. ${ }^{166}$ At the same time, it is crucial to understand that there is considerable and perhaps surprising overlap between the libertarian and liberal perspectives-far more so than one would think if one focused on the polarized political rhetoric in the United States. At the very least, democracies require (1) that there be many owners, (2) that opportunities to acquire the property needed for a full human life are universally (and readily) available, and (3) that the scope of the powers granted to owners must be subject to rules that reflect both democratic processes and individual rights to liberty and to equal, dignified treatment.

A couple of examples may help us see the fundamental normative questions underlying the basic structure of property law. Consider the seemingly minor topic of beach access. The state of Hawaii grants every person the right to go to the beach anywhere in the state. ${ }^{167}$ Most states allow public recreational access to the wet sand area up to the high-tide line.$^{168}$ Unlike the rest of the country, Massachusetts and Maine do not even allow public recreational uses

166. Compare NOZICK, supra note 142, at 171-72 ("Whether it is done through taxation... or through seizure of profits,... principles of distributive justice involve appropriating the actions of other persons. . . [It] makes them a part-owner of you ...."), with RAWLS, supra note $165, \S 32.6$, at 114-15 ("Among the basic rights is the right to hold and to have the exclusive use of personal property. One ground of this right is to allow a sufficient material basis for personal independence and a sense of self-respect . ...”).

167. See In re Ashford, 440 P.2d 76, 77-78 (Haw. 1968); SINGER, supra note 33, § 2.8, at 90.

168. SINGER, supra note $33, \S 2.8$, at $87-90$. 
of the privately held tidelands. ${ }^{169}$ In those states, public access rights over the wet sand area up to the high-tide line are limited to navigation and fishing purposes. ${ }^{170}$ Seaside owners own their beaches down to the low-tide line and have the right to exclude all others. ${ }^{171}$ In contrast, the state of Hawaii grants recreational beach access rights not only on the wet sand up to the high-tide line but also on the dry sand area up to the vegetation line. ${ }^{172}$ Shorefront owners have an obligation to allow others to hang out on the dry sand beach in front of their own homes; they simply do not own the right to exclude others from this area. ${ }^{173}$

This Hawaiian property rule may seem like a detail of the property system rather than a core issue affecting the basic structure of property-but nothing could be further from the truth. The law of beach access in Hawaii has an enormous, incalculable impact on social life. Though the law limits the property rights of beachfront owners as they are defined elsewhere, it increases the wealth of every single person in the state by giving them a right to go to the beach anywhere in the state. Everyone, no matter how poor, has a backyard on the beach. Individuals and families go the shore in the morning to swim or surf before work. Families gather to watch the sun go down in the evening. Even if they only have a small apartment inland, they have a right to sit outside on the beach wherever they please. The beach access rule dramatically shapes the character and quality of social life. It is a right that Hawaiians have come to take for granted and that most cherish. It affects the range of options people have, their daily routine, and the sense of satisfaction of almost everyone.

Suppose a state court in Massachusetts decided to adopt the Hawaiian rule. Would this constitute a taking of property without just compensation? Four Justices on the Supreme Court would likely say "yes" because this would constitute a taking of an "established right of private property," that is, the right to exclude nonowners from the dry sand in front of one's home. ${ }^{174}$ But perhaps not: after all, the Supreme Court did hold that a California constitutional right to enter

169. See Bell v. Town of Wells, 557 A.2d 168, 174-76 (Me. 1989); Opinion of the Justices, 313 N.E.2d 561, 568-71 (Mass. 1974); SINGER, supra note 33, § 2.8, at 88-89.

170. SINGER, supra note $33, \S 2.8$, at 88 .

171. See id. at $88-89$.

172. Id. at 89-90.

173. See In re Ashford, 440 P.2d 76, 77-78 (Haw. 1968); SINGER, supra note 33, § 2.8, at 90.

174. See Stop the Beach Renourishment, Inc. v. Fla. Dep't of Envtl. Prot., 130 S. Ct. 2592, 2602 (2010) (plurality opinion); Opinion of the Justices, 313 N.E.2d at 567. 
shopping centers to hand out leaflets did not violate the constitutionally protected property rights of the owner. ${ }^{175}$ Neither the federal public accommodations law nor the Fair Housing Act constitutes a taking of property in violation of the Constitution even though those statutes require owners to refrain from excluding customers or tenants because of their race. ${ }^{176}$ Would it be unfair to redistribute rights from beachfront owners to the public, or would this merely constitute a modernization of a common law rule based on changing social values? Should the rule adopted by the state courts in Massachusetts in colonial times be immune from change, or should the states that adopted one approach be entitled to move to another? Would it constitute a taking of a public easement of beach access if the Hawaii legislature were to adopt the Massachusetts rule?

Answering these questions requires us to consider the role of beach access in social life and whether we understand legitimate interests in that area to be static and immune to legislative change or dependent on shifting understandings of the obligations that owners owe and the rights that owners have. We must consider the kind of social life our property norms reflect and shape and the distribution of opportunities they embrace or exclude. We must consider the legitimacy of various expectations and the justifiability of the exercise of various powers. What do we have a right to expect? What underlying framework is consistent with our best understanding of the relative rights of beachfront owners and the general public? Is the right to exclude others from the beach in front of one's house one of the types of property rights that democracies should no longer recognize? Does it deny equal concern and respect to each person to deny nonowners the right to go to the beach on terms that make it in fact accessible to them?

Political, moral, and legal theory all help us think about these questions because they define the contours of a democratic state. Both moral and legal theory insist that we look at the issue from the perspective of everyone affected by it. Can we give reasons for our choices that could or should be accepted by those who have to live with them? Modern political theory suggests that property rights

175. PruneYard Shopping Ctr. v. Robins, 447 U.S. 74, 82-84 (1980).

176. See, e.g., Heart of Atlanta Motel, Inc. v. United States, 379 U.S. 241, 261 (1964) (holding that the public-accommodations law of 1964 does not constitute an unconstitutional taking of property without just compensation). No challenges have been brought to the Fair Housing Act on the ground that it takes property without just compensation. 
should be allocated and defined in a manner that accords with a basic framework of society that is consistent with democratic political and social values in a society characterized by pluralism in comprehensive normative views. The basic values that democracies accept are implicated in such decisions. What do liberty and equality mean in this context? What opportunities do we think should be open to each person? Is beach access one of them?

Libertarians like Nozick would probably say no; beach access is not a necessity, and we are all better off allocating control over land to private individuals who act as gatekeepers to their property. Beachfront owners cannot enjoy privacy or security if strangers have the right to sit in their backyard. Once private rights in beaches are established, it would violate the reasons we created the state in the first place to allow legislatures to deprive people of their duly established property rights. But liberals like Rawls might approach the question in another way entirely. What rule might we adopt if we did not know whether we would be beachfront owners or whether we would have enough money to buy such access? Would we choose to allow a minority to monopolize enjoyment of beaches? The libertarian way of posing the question is likely to result in favoring exclusionary rights, while the liberal "veil of ignorance" reasoning is more likely to favor public access. Figuring out which approach is the best interpretation of our values of liberty, equality, and democracy is necessary to answering the question of what we should do.

If this example seems too unimportant or esoteric, consider subprime mortgages. Should we enact regulations that protect borrowers from entering adjustable-rate mortgage agreements when they are unlikely to be able to make the payments when the interest rate goes up? The Massachusetts Supreme Judicial Court held that a jury might well conclude that it constitutes an unfair practice in violation of the state's consumer protection act to grant an adjustablerate mortgage-backed loan to a borrower when it was evident the borrower did not have a sufficient income to pay back the loan when the interest rate adjusted upwards. ${ }^{177}$ As the court stated there,

To issue a home mortgage loan whose success relies on the hope that the fair market value of the home will increase during the introductory period is as unfair as issuing a home mortgage loan

177. Commonwealth v. Fremont Inv. \& Loan, 897 N.E.2d 548, 557-62 (Mass. 2008). 
whose success depends on the hope that the borrower's income will increase during that same period.

Similarly, the Mortgage Reform and Anti-Predatory Lending Act of $2010,{ }^{179}$ passed as one part of the Dodd-Frank Wall Street Reform and Consumer Protection Act, ${ }^{180}$ makes a consumer's ability to repay a condition for a creditor's granting a residential mortgage. ${ }^{181}$ Final regulations have now been issued that prevent the granting of highpriced mortgages to those who cannot afford them and provide presumptive protection for "qualified mortgages" that meet certain affordability criteria. ${ }^{182}$

We could allow such agreements to be made on the libertarian grounds that individuals should be free to make whatever agreements they like and take whatever risks they please whether or not they would agree if they had full information. Or we could ban them because we have enough experience to know that the vast majority of people who enter such agreements do so because they do not fully understand them or because we are sure that almost everyone who does so regrets it later. Is it better to have owned and lost than never to have owned at all? Banning subprime mortgages could be justified on the libertarian grounds that it prevents fraud or on the liberal grounds that it establishes minimum standards of fair treatment for consumers entering the marketplace, ensuring they get what they think they are paying for. Allowing subprime mortgages arguably promotes the autonomy of borrowers and lenders alike, making them masters of their own fates. ${ }^{183}$ Which interpretation is better?

Answering this question requires normative judgments that cannot be addressed by an economic cost-benefit analysis or a laserlike focus on the information costs of the alternative solutions. Rather, we are confronted with a choice among values. Are subprime mortgages a shining example of individuals exercising autonomy by

178. Id. at 554 (quotation marks omitted).

179. Mortgage Reform and Anti-Predatory Lending Act of 2010, Pub. L. No. 111-203, tit. 14, 124 Stat. 2136 (codified in scattered sections of 12, 15, and 42 U.S.C.).

180. Dodd-Frank Wall Street Reform and Consumer Protection Act, Pub. L. No. 111-203, 124 Stat. 1376 (2010) (codified as amended in scattered sections of the U.S.C.).

181. 15 U.S.C. $\$ 1639 \mathrm{c}(2012)$.

182. See Ability-to-Repay and Qualified Mortgage Standards Under the Truth in Lending Act (Regulation Z), 78 Fed. Reg. 6408, 6408-09 (Jan. 30, 2013) (to be codified at 12 C.F.R. pt. 1026).

183. See Singer, supra note 64 (exploring the arguments for and against regulating the terms of subprime mortgages). 
taking reasonable risks, or are they perfect examples of the ways unscrupulous peddlers can pick our pockets? One might think that libertarians would be happy to allow freedom of contract while liberals would want consumer protection. But it is not clear that libertarians should be so happy with deceptive sales techniques; after all, deceptive sales practices shade into fraud, and fraud shades into theft. Libertarians favor free choice, but they also favor strong protection for property rights. For that reason, they are usually strong opponents of fraud. Deceptive conduct promotes, not freedom of contract, but deals the parties would not have made had they understood what they were actually purchasing. And liberals may worry that banning subprime mortgages deprives the poor of the only path they have to home ownership.

Nor does efficiency theory give us a clean answer. If information costs are a form of transaction cost, then the question is what agreement the parties would (or would not) have made if they had perfect information. As a counterfactual question, judgment needs to be exercised to answer this question: Do we focus on the regret that subprime mortgage borrowers feel when things go sour or their joy at the initial deal that allowed them to buy a house? Do we accept the reasoning of Professor Alan Schwartz, who argues that any limitations on freedom of contract simply prevent people from "do[ing] the best they can for themselves, given their circumstances"? ${ }^{184}$ Or should we allow subprime mortgages on the grounds that they are the only path for home ownership for the poor or those with poor credit ratings? Or do we adopt the approach of economist Joseph Stiglitz, who argues "[ $\mathrm{t}]$ here was no point of putting someone in a home for a few months and then tossing him out after having stripped him of his life savings. But that was what the banks were doing"? ${ }^{185}$ Should we protect people from decisions they are very likely to regret and promote housing for poor people by methods that do not leave them worse off than before? Whatever choice we make, we will be establishing minimum standards for market transactions consistent with the injunction to treat others with dignity and respect.

184. Alan Schwartz, Justice and the Law of Contracts: A Case for the Traditional Approach, 9 HARV. J.L. \& PUB. POL'Y 107, 108 (1986).

185. Joseph E. Stiglitz, Freefall: America, Free Markets, And the Sinking of THE WORLD ECONOMY 11 (2010). 
Figuring out whether to allow or prohibit beach access or subprime mortgages depends on an interpretation of the values of liberty, dignity, equality, and democracy. We have no magic formula that tells us what those concepts mean. But that does not mean that our consideration of what they entail is totally arbitrary. ${ }^{186}$ Despite the contentious political debates between libertarians and liberals and between utilitarian, deontological, and virtue theories of moral reasoning, there are some values we hold to be "self-evident." libertarians and liberals favor equality, liberty, the rule of law, and democratic government. That means that despite the heated rhetoric surrounding the concept of "regulation," there is an American consensus that we need laws that establish rules of the road and minimum standards for property and contract law. ${ }^{188}$ Those minimum standards not only facilitate and coordinate free choices among individuals and lower the costs of transactions and information about ownership. They also establish norms of conduct consistent with our commitment to treat each person with respect and dignity.

Because we are a society committed to the ideas of democracy and human rights, we do not satisfy all preferences no matter what they happen to be. Some preferences are off the table, so to speak. We do not carefully consider the costs and benefits of adopting slavery as a social or economic system; rather, we outlaw it as inconsistent with the norms governing a free and democratic society that treats each person with equal concern and respect. Similarly, we do not allow strict foreclosure or unfair or deceptive business practices, and we do not sit back and do nothing when bankers create mortgages that wreck the world economy.

\section{CONCLUSION}

Property law is not simply about best management practices or coordination in the face of scarcity. Democracies elect leaders who pass laws that establish minimum standards for social and economic relationships compatible with our justified expectations and our considered judgments about what it means to treat others with dignity and respect. Property law is not just a mechanism of coordination; it is

186. See Henry S. Richardson, PracticAl REASONIng AbOUT FinAl Ends 9 (1994); Singer, Normative Methods, supra note 55, at 903-05.

187. THE DEClARATION OF INDEPENDENCE para. 2 (U.S. 1776).

188. Singer, supra note 43 , at $155-58$. 
a quasi-constitutional framework for social life. Property is not merely the law of things. Property is the law of democracy. 